\title{
Physicochemical and functional characterization of a biosimilar adalimumab ZRC-3|97
}

\author{
Sanjay Bandyopadhyay \\ Mukesh Mahajan \\ Tulsi Mehta \\ Arun K Singh \\ Aashini Parikh \\ Ajit K Gupta \\ Pankaj Kalita \\ Mihir Patel \\ Sanjeev Kumar Mendiratta \\ Zydus Research Centre, Biotech \\ Division, Cadila Healthcare Ltd, The \\ Zydus Group, Ahmedabad, Gujarat, \\ India
}

This article was published in the following Dove Press journal:

Biosimilars

31 December 2014

Number of times this article has been viewed

\begin{abstract}
ZRC-3197 has been developed indigenously by Cadila Healthcare Ltd as a biosimilar adalimumab of originator HUMIRA ${ }^{\circledR}$. Biosimilarity has been demonstrated with a comprehensive set of state-of-the-art analytical techniques to characterize the physicochemical and functional properties of ZRC-3197 in comparison with originator HUMIRA ${ }^{\circledR}$. The biosimilar ZRC-3197 showed indistinguishable primary and secondary structures with similar level of purity and heterogeneity as compared to that of the originator product. When analyzed, in parallel, the two products were observed to show a high degree of sameness of the carbohydrate structure and charge heterogeneity profile. Both biosimilar ZRC-3197 and the originator HUMIRA ${ }^{\circledR}$ appeared to show highly comparable key functional properties, as assessed by in vitro cell-based assay and surface plasmon resonance technique. The biosimilar ZRC-3197 exhibited highly similar tumor necrosis factor alpha neutralizing activity as well as binding affinity for Fc $\gamma$ RIIIa receptor compared to that of the originator product. The biosimilar ZRC-3197 was observed to show similar level of efficacy and safety profile in rheumatoid arthritis patients, when submitted to a head-to-head double-blind trial, in India, with the originator (reference) product, HUMIRA ${ }^{\circledR}$. Based on the demonstrated biosimilarity, market authorization has been granted for ZRC-3197, as a biosimilar of originator HUMIRA ${ }^{\circledR}$, in India. Here, we report the characterization of physicochemical and functional properties of the biosimilar ZRC-3197 and originator HUMIRA ${ }^{\circledR}$.
\end{abstract}

Keywords: adalimumab, biosimilars, tumor necrosis factor (TNF)

\section{Introduction}

Biosimilars are defined as "similar" or "highly similar" to the reference medicinal products (originator products) following the EMA (European Medicines Agency) and the US FDA (Food and Drug Administration) regulatory guidelines, respectively. ${ }^{1-3}$ Following a specific regulatory pathway, the EMA has already approved a number of biosimilar products, mainly the first-generation cytokines, in Europe, for which the patents on originators have expired. In 2012, the EMA also issued guidelines on the development of biosimilar monoclonal antibodies, with special emphasis on non-clinical and clinical issues. ${ }^{4}$ Recently, the EMA has approved the first biosimilar monoclonal antibody, Remsima $^{\mathrm{TM}}$ (or Inflectra ${ }^{\mathrm{TM}}$ ), a biosimilar of originator infliximab $\left(\right.$ Remicade $\left.^{\circledR}\right)$. On the other hand, in early 2012 the FDA released draft guidance for the development and regulatory review of the biosimilars, which has not yet been implemented. In India, the biosimilars are termed as "similar biologics" in accordance with the guidelines issued by the Central Drugs Standard Control Organization (CDSCO, a branch of the Ministry of Health and Family Welfare, Government of India). CDSCO, in conjunction with the Ministry of Health and Family Welfare, issued specific guidelines in
Correspondence: Sanjay Bandyopadhyay Zydus Research Centre, Biotech Cadila Healthcare Ltd (Zydus group), Sarkhej-Bavla, NH 8A, Moraiya, Ahmedabad 382210, Gujarat, India Tel +9l 27 I766 5555 ext 6I4 Email sanjaybandyopadhyay@zyduscadila. com 
2012 on regulatory requirements for market authorization of biosimilar products. ${ }^{5}$

Use of biologically derived therapeutic monoclonal antibodies has proven extremely beneficial to a large pool of patients across the world. ${ }^{6,7}$ With the increasing use of monoclonal antibodies, especially in the areas of cancer and autoimmune disease, there has been a great demand for the development of biosimilar therapeutic monoclonal antibodies. Biosimilars having a similar level of efficacy and safety compared to that of the originator products provide additional advantages to patients in terms of affordability and low cost of therapy, while expanding patient access to therapies. Despite its complex molecular nature, a targetdirected approach for development has proven highly successful in generating monoclonal antibodies similar to the originator products, at the level of individual quality attributes with the same functional properties. ${ }^{8,9}$ In the absence of any knowledge about the originator process, an iterative process is employed to achieve the desired quality attributes for the biosimilar product during process development, which eventually leads to a final process and delivers the desired product similar to the originator. In the process, biosimilars are developed by using the same host system harboring the gene that encodes the same amino acid sequence (primary structure) as that of the targeted originator product. It is described in FDA draft guidance for biosimilars that the more comprehensive and robust the comparative structural and functional characterizations are, the stronger the scientific justification there is for a selective and targeted approach to animal and/or clinical testing. ${ }^{3}$

In this present report, we have demonstrated biosimilarity of ZRC-3197 to originator HUMIRA ${ }^{\circledR}$ with a comprehensive comparability program using state-of-the-art analytical tools. ZRC-3197 has been developed indigenously by Cadila Healthcare Ltd, as a biosimilar medicinal product of originator HUMIRA ${ }^{\circledR}$. Originator HUMIRA ${ }^{\circledR}$, a tumor necrosis factor alpha blocker, is used for the treatment of rheumatoid arthritis, juvenile idiopathic arthritis, psoriatic arthritis, ankylosing spondylitis, Crohn's disease, and plaque psoriasis. Adalimumab, which delivers the same active substance as originator HUMIRA ${ }^{\circledR}$, is a fully human monoclonal immunoglobulin G1 antibody produced recombinantly in genetically engineered Chinese hamster ovary (CHO) cells. Adalimumab is composed of 1,330 amino acids with a molecular weight of approximately $148 \mathrm{kDa}$. Here, we report the characterization data of physicochemical and functional properties of ZRC3197 and originator HUMIRA ${ }^{\circledR}$, on a comparative basis, to demonstrate biosimilarity.

\section{Materials and methods}

Multiple lot/batch materials of originator adalimumab product (HUMIRA ${ }^{\circledR} ; 40 \mathrm{mg} / 0.8 \mathrm{~mL}$ pre-filled syringe; AbbVie Inc., Chicago, IL, USA) were sourced directly from US and EU markets with appropriate shipping records to carry out the comparative physicochemical and functional characterization tests with the biosimilar ZRC-3197. The biosimilar ZRC-3197, which has been used for current comparability studies, was generated with the final manufacturing process developed by Cadila Healthcare Ltd. Upon receiving the originator product, HUMIRA ${ }^{\circledR}$ was stored, under refrigerated conditions (between $2^{\circ} \mathrm{C}$ and $8^{\circ} \mathrm{C}$ ) until use, as recommended by the manufacturer.

\section{Cloning, cell culture, and purification}

ZRC-3197 was produced in genetically engineered CHO cells harboring the heavy- and light-chain genes of adalimumab. Gene cloning was performed following the nucleotide sequence of D2E7 (adalimumab) clone, published previously as patents. ${ }^{10,11}$ After codon optimization, genes that encode the light-chain (variable and constant regions) and heavy-chain (variable and constant regions) components of adalimumab were chemically synthesized at GeneArt Lab, a division of Thermo Fisher Scientific, Waltham, MA, USA. Following cloning of the heavy- and light-chain genes in suitable mammalian expression vectors, transfections were carried out in $\mathrm{CHO}$ cells. Nucleotide sequence of the gene integrated in the $\mathrm{CHO}$ cell genome was confirmed by sequencing of complementary DNAs on an ABI 3500 Genetic Analyzer (ABI, CA, USA). Through an extensive clone screening process (limiting dilution), a $\mathrm{CHO}$ production clone for the biosimilar ZRC-3197 was selected. The CHO production clone was selected on the basis of phenotypic stability, productivity, and key quality properties of the desired product. Upstream production of the biosimilar ZRC-3197 by $\mathrm{CHO}$ cells was performed in a bioreactor. Purification of the biosimilar ZRC-3197 was conducted by using a series of conventional column chromatography and membrane filtration techniques with dedicated viral inactivation (low$\mathrm{pH}$ ) and virus clearance (by nano-filtration) steps. Finally, after purification, the biosimilar ZRC-3197 was prepared at $50 \mathrm{mg} / \mathrm{mL}$ in the form of drug product and filled in $1 \mathrm{~mL}$ prefilled syringes with a fill volume of $0.8 \mathrm{~mL}$ ( $40 \mathrm{mg}$ strength) or $0.4 \mathrm{~mL}$ (20 mg strength), like the originator HUMIRA ${ }^{\circledR}$ product. To demonstrate biosimilarity of ZRC-3197, a series of physicochemical and functional characterization tests were performed in comparison with the originator $\mathrm{HUMIRA}^{\circledR}$, in a side-by-side manner. 


\section{Protein concentration assay}

Concentration of protein in the drug product preparations was determined by optical density (OD) ${ }_{280 \mathrm{~nm}}$ method on an ultraviolet (UV)-visible spectrophotometer (Shimadzu Corporation, Kyoto, Japan) using an extinction-coefficient value reported in patent US 20070292442A1. ${ }^{12}$

\section{Peptide sequencing, disulfide bridge mapping, and post-translational modifications by mass spectrometry}

Amino acid sequence analysis, disulfide (S-S) bridge mapping, and analysis for potential post-translational modifications in adalimumab were performed by using liquid chromatography-tandem mass spectrometry (LC-MS-MS; 4000 QTrap, Thermo Fisher Scientific) and matrix-assisted laser desorption-ionization time-of-flight mass spectrometry (MALDI-TOF-MS; Voyager DE-STR, Thermo Fisher Scientific) techniques. Experiments were carried out with the originator HUMIRA ${ }^{\circledR}$ and biosimilar ZRC-3197 preparations, in a side-by-side manner, at Intertek Pharmaceutical Services, Manchester, UK. Various experimental conditions, like sequence-specific enzymatic cleavage or site-specific chemical cleavage, were applied to obtain the desired peptide fragments of adalimumab protein, prior to MS or MS-MS analysis. Enzymatic digestions were performed either insolution or in-gel by using trypsin or Glu C or Lys C or Asp $\mathrm{N}$ or chymotrypsin, or a combination thereof, whereas chemical digestion was carried out in solution by using cyanogen bromide $(\mathrm{CNBr})$ for that specific purpose. Furthermore, enzymatic or chemical digestion was carried out on both formulated and deformulated adalimumab preparations, prior to MS analysis. MS-MS data for sequence analysis were acquired using information-dependent acquisition (IDA) method, and data obtained from IDA analysis were searched against a database containing either the expected heavy-chain sequence or the expected light-chain sequence of adalimumab using the MASCOT search engine. MALDI-TOF-MS data were analyzed in positive ion reflectron acquisition mode, and a peptide calibration mixture (ABSciex Calibration Kit; Cat No P2-3143-00) was used to calibrate the data acquired.

\section{Peptide mapping by RP-HPLC-UV}

Reverse-phase high-performance liquid chromatography with ultraviolet light (RP-HPLC-UV) detection was performed to separate the trypsinized peptide fragments of adalimumab. Samples containing $200 \mu \mathrm{g}$ adalimumab protein dissolved in $40 \mathrm{mM}$ ammonium bicarbonate solution $(\mathrm{pH} \mathrm{8.0)}$ in the presence of $10 \%$ non-ionic detergent, Empigen, were reduced by
$4 \mathrm{mM}$ dithiothreitol at $50^{\circ} \mathrm{C}$ for 30 minutes. After reduction, protein samples were carboxyamidated in the presence of $8 \mathrm{mM}$ iodoacetamide for 40 minutes at room temperature, under cover of darkness. Following carboxyamidation, samples were digested with L-(tosylamido-2-phenyl) ethyl chloromethyl ketone-trypsin at 1:20 (TPCK-trypsin:adalimumab) ratio, at $37^{\circ} \mathrm{C}$ for 16 hours, at which time reactions were terminated with the addition of $0.1 \%$ trifluoroacetic acid (TFA) solution at a $1: 1$ ratio $(\mathrm{v} / \mathrm{v})$. Aliquots of $50 \mu \mathrm{L}$ tryptic digest were analyzed on a LC2010-CHT series Shimadzu HPLC (Shimadzu Corporation, Kyoto, Japan) system equipped with a C18-RP-HPLC column $(4.6 \times 250 \mathrm{~mm}, 5 \mu \mathrm{m}$; GRACE VYDAC) at $45^{\circ} \mathrm{C}$. Elution of peptide fragments was carried out with $0 \%-45 \%$ linear gradient of solvent $\mathrm{B}(0.1 \%$ TFA in $100 \% \mathrm{ACN}$ ) for 115 minutes followed by a 10 -minute linear gradient from $45 \%-65 \%$ of solvent B ( $0.1 \%$ TFA in $100 \%$ $\mathrm{ACN})$. Elution was monitored at $214 \mathrm{~nm}$ with UV detection at a flow rate of $1 \mathrm{~mL} /$ minute.

\section{Molecular mass}

Molecular masses of the originator HUMIRA ${ }^{\circledR}$ and biosimilar ZRC-3197 were determined by mass spectrometry (MS) on an ABI 4800 MALDI-TOF-TOF-MS in linear mid-mass positive mode at Advanced Molecular Biology, Vimta Labs Ltd, Hyderabad, India. Experiments were carried out, under both reduced and intact non-reduced conditions, following standard protocols. For mass analysis of the heavy- and lightchain components, separately, samples were reduced, first with dithiothreitol, and then were isolated by RP-HPLC. MS data acquisition was performed by using 4000-series Data Explorer $^{\mathrm{TM}}$ software.

\section{Polypeptide profile}

Polypeptide profile of adalimumab present either in originator HUMIRA $^{\circledR}$ or in biosimilar ZRC-3197 drug product preparation was analyzed by sodium dodecyl sulfate polyacrylamide gel electrophoresis (SDS-PAGE) method, under reducing (12\% SDS-PAGE) and non-reducing (7\% SDS-PAGE) conditions using Mini-PROTEAN ${ }^{\circledR}$ (Bio-Rad Laboratories Inc., Hercules, CA, USA) gel apparatus, essentially following the manufacturer's instructions. Samples containing $1 \mu \mathrm{g}$ adalimumab were loaded in each lane of the gel, and electrophoresis was conducted at $25 \mathrm{~mA}$ constant current, under room-temperature conditions. Protein bands resolved on gel were developed by ammonical silver-staining method. ${ }^{13}$

Capillary electrophoresis in the presence of SDS (CESDS) was performed on a Beckman PA800 Plus instrument equipped with a $50 \mu \mathrm{m} \times 30.2 \mathrm{~cm}$ uncoated capillary, 
in accordance with the manufacturer's instructions (Beckman Coulter Inc., Pasadena, CA, USA). For non-reducing CESDS, samples of adalimumab at $1 \mathrm{mg} / \mathrm{mL}$ were mixed with SDS sample buffer and alkylated with $12.25 \mathrm{mM}$ iodoacetamide (Sigma). Alkylated samples were mixed with a calibration standard (10 kDa, Beckman), and the mixture was heated at $70^{\circ} \mathrm{C}$ for 3 minutes. For reducing CE-SDS analysis, samples at $1 \mathrm{mg} / \mathrm{mL}$ were mixed with SDS sample buffer and reduced with the addition of $5 \mu \mathrm{L}$ of $\beta$-mercaptoethanol (Sigma). After reduction, samples were mixed with a calibration standard (10 kDa, Beckman), and the mixture was heated at approximately $100^{\circ} \mathrm{C}$ for 3 minutes. A set of known SDS molecular weight size standards $(10,20,35,50,100,150$, and $225 \mathrm{kDa}$ ) were used as the calibration standard for CE-SDS analysis. Injection of the samples was performed at $5 \mathrm{kV}$ for 20 seconds, followed by separation of protein at $15 \mathrm{kV}$ for 30 minutes in reverse polarity at $25^{\circ} \mathrm{C}$. Separation was monitored with photodiode array detection at $220 \mathrm{~nm}$.

\section{Purity}

High-performance analytical size-exclusion chromatography (HP-SEC) was performed on an LC2010-CHT series Shimadzu HPLC system equipped with a TSK-Gel G3000SWXL column ( $7.8 \times 300 \mathrm{~mm}, 5 \mu \mathrm{m}$; Tosoh, Tokyo, Japan) to check the purity of adalimumab protein on the basis of molecular sizes. The column was equilibrated with $50 \mathrm{mM}$ sodium phosphate buffer of $\mathrm{pH} 6.8$, containing $300 \mathrm{mM} \mathrm{NaCl}$ at $30^{\circ} \mathrm{C}$. Samples containing $10 \mu \mathrm{g}$ adalimumab were analyzed at a flow rate of $0.5 \mathrm{~mL} /$ minute in an isocratic mode, and chromatographic separation was monitored at $214 \mathrm{~nm}$ with UV detection.

\section{Charged species variants}

High-performance analytical ion exchange chromatography (HP-IEC) was performed on an LC2010-CHT series Shimadzu HPLC system equipped with a weak cation exchange TSK-Gel CM-STAT column $(4.6 \times 100 \mathrm{~mm}$, $7 \mu \mathrm{m}$; Tosoh) to detect various charged species variants of adalimumab. Prior to injection, the column was saturated with $95 \%$ mobile phase A (20 mM sodium phosphate buffer, $\mathrm{pH} 6.9)$ and $5 \%$ mobile phase $\mathrm{B}(20 \mathrm{mM}$ sodium phosphate buffer, pH 6.9 containing $200 \mathrm{mM} \mathrm{NaCl}$ ) at $40^{\circ} \mathrm{C}$ with a flow rate of $1 \mathrm{~mL} / \mathrm{minute}$. Aliquots of $50 \mu \mathrm{g}$ adalimumab were injected for analysis. Differently charged species variants of adalimumab were separated out of the column with a 50 -minute linear gradient from 5\%-35\% of mobile phase B, under the same conditions. The chromatographic separation was monitored at $280 \mathrm{~nm}$ with UV detection.
Capillary isoelectric focusing (cIEF) of adalimumab samples was performed on a Beckman PA800 Plus instrument. Samples containing $50 \mu \mathrm{g}$ adalimumab was mixed with $2.4 \mathrm{M}$ urea-cIEF gel, $4.8 \%$ pharmalyte ${ }^{\circledR}$ (three to ten carrier ampholytes), $40 \mathrm{mM}$ L-arginine, $1.6 \mathrm{mM}$ iminodiacetic acid, and pI markers (pI 10, pI 7, and pI 4.1) in a total volume of $250 \mu \mathrm{L}$ as per the manufacturer's instructions (Beckman Coulter). Samples were pressure-injected on to a neutral coated eCAP ${ }^{\mathrm{TM}}$ capillary $(50 \mu \mathrm{m} \times 20 \mathrm{~cm})$, and focusing was performed with $30 \mathrm{kV}$ for 30 minutes at $25 \mathrm{psi}$ and $20^{\circ} \mathrm{C}$. Electropherogram was monitored at $280 \mathrm{~nm}$ with UV detection.

\section{Glycan analysis}

Adalimubab's N-glycan profile was analyzed after separating the carbohydrate moieties from protein by PNGase treatment. Aliquots of $300 \mu \mathrm{g}$ adalimumab samples dissolved in $50 \mathrm{mM}$ sodium phosphate, $\mathrm{pH} 7.5$ containing $50 \mathrm{mM}$ $\beta$-mercaptoethanol, $0.75 \%$ nonidet 40 , and $0.02 \%$ sodium azide were treated with $3 \mathrm{U}$ of PNGase for 16 hours at $37^{\circ} \mathrm{C}$. Following incubation, the sample mixture was treated with cold ethanol to precipitate the protein, and clear supernatant containing the glycan moieties was collected by centrifugation. Extracted glycans were labeled with a fluorescent dye, 2-AB (2-aminobenzamide), in the presence of sodium cyanoborohydrate for 3 hours at $65^{\circ} \mathrm{C}$, in dark conditions. After labeling, excess amounts of dye were removed from the mixture by using a desalting cartridge. Desalted samples were vacuum-dried and reconstituted in deionized water for further analysis. Glycan analysis was performed with the reconstituted samples on a Nexera UHPLC (ultra-high-performance liquid chromatograph) from Shimadzu equipped with an ACQUITY UPLC ${ }^{\circledR}$ BEH Glycan column $(2.1 \times 100 \mathrm{~mm}$; $1.7 \mu \mathrm{m})$ from Waters. The column was saturated with $22 \%$ mobile phase $\mathrm{A}(0.1 \mathrm{M}$ ammonium formate, $\mathrm{pH} 4.5)$ and $78 \%$ mobile phase B (100\% ACN). Different glycan moieties were separated out of the column with a 38.5-minute linear gradient from $78 \%-55.9 \%$ mobile phase $\mathrm{B}$ at $0.5 \mathrm{~mL} /$ minute at $60^{\circ} \mathrm{C}$. Elution of the glycans was monitored with fluorescence detection with excitation at $330 \mathrm{~nm}$ and emission at $420 \mathrm{~nm}$. Different glycan moieties extracted from adalimumab preparations were detected, with respect to a set of standard glycans $\left(\right.$ Glyko $^{\circledR}$ human immunoglobulin G N-linked glycan library from Prozyme, Hayward, CA, USA), which were analyzed under the same conditions.

\section{Neutral and amino sugars analysis}

Concentrations of fucose, galactosamine, glucosamine, galactose, and mannose in intact adalimumab preparations 
(originator HUMIRA ${ }^{\circledR}$ and biosimilar ZRC-3197) were determined following acid hydrolysis by high-performance anion exchange chromatography with pulsed amperometric detection (HPAEC-PAD) on a Dionex ICS-3000 system with electrochemical (amperometric) detection and equipped with a CarboPac PA1 column $(2 \times 250 \mathrm{~mm})$, at Intertek Pharmaceutical Services, Manchester, UK. Samples containing $200 \mu \mathrm{g}$ adalimumab were mixed with TFA (15\% final) and heated for 4 hours (approximately) at $100^{\circ} \mathrm{C}$ to facilitate hydrolysis. The hydrolyzed samples were taken to dryness in a vacuum centrifuge, and the dried material was reconstituted in $500 \mu \mathrm{L}$ deionized water, prior to analysis. A mixture of known concentrations of standard monosaccharides was used to construct a calibration curve and for determination of the total sugars present either in originator HUMIRA ${ }^{\circledR}$ or in biosimilar ZRC-3197 preparation.

\section{Secondary structure}

Circular dichroism (CD) spectroscopy experiments were carried out on a JASCO J-810 spectrometer to compare the secondary structure of originator HUMIRA ${ }^{\circledR}$ and biosimilar ZRC-3197, at $0.25 \mathrm{mg} / \mathrm{mL}$, in the far-UV region (250-190 nm), under room temperature conditions. Three consecutive scans were accumulated for each sample and the spectra thus obtained were averaged.

\section{Estimation of free thiols}

Free thiol estimation with adalimumab samples (HUMIRA ${ }^{\circledR}$ and ZRC-3197), at $2 \mathrm{mg} / \mathrm{mL}$, was carried out in a side-by-side manner, under denaturing conditions by DTNB ( $5,5^{\prime}$-Dithiobis-(2-nitrobenzoic acid). Reactions were performed for 1 hour at room temperature and monitored at $412 \mathrm{~nm}$ with the release of thionitrobenzoate $\left(\varepsilon=14,150 \mathrm{M}^{-1} \mathrm{~cm}^{-1}\right)$. Values were calculated using the extinction coefficient value of thionitrobenzoate as number of free cysteine $(-\mathrm{SH})$ modified per mole of protein.

\section{Affinity for TNF and FcyRIIla}

Affinity of adalimumab for recombinant human TNFalpha (R-HuTNF- $\alpha$ ) was determined by using surface plasmon resonance (SPR) technique on a Biacore T200 (GE Healthcare) instrument. First, binding of adalimumab samples $(0.25 \mathrm{mg} / \mathrm{mL})$ on immobilized Protein A (Pierce) matrix was performed at a flow rate of $10 \mu \mathrm{L} /$ minute for 60 seconds. Protein A was immobilized to the carboxymethyl dextran-coated CM5 sensor chips using standard amine coupling chemistry to obtain an immobilization level of $\sim 1,500$ RU. Solution of R-HuTNF- $\alpha$ at different concentrations $-2 \mathrm{nM}, 4 \mathrm{nM}, 6 \mathrm{nM}, 8 \mathrm{nM}, 16$ $\mathrm{nM}$, and $32 \mathrm{nM}$ - was injected on the bound adalimumab at a flow rate of $25 \mu \mathrm{L} /$ minute for 300 seconds for association. For dissociation of TNF, HBS-EP+ buffer (HEPES [4-\{2-hydroxyethyl\}-1-piperazineethanesulfonic acid], $\mathrm{NaCl}$, EDTA [ethylenediaminetetraacetic acid], and Surfactant P20 from GE Healthcare Life Sciences) was injected at a flow rate of $25 \mu \mathrm{L} /$ minute for 300 seconds. Biosensor matrices were regenerated using glycine- $\mathrm{HCl}, \mathrm{pH}$ 2.0. Biacore T200 evaluation software (version 1.0) was used to determine $k$ (dissociation constant) and $k_{a}$ (association constant) values.

Affinity of adalimumab to recombinant human Fc $\gamma$ RIIIa (CD16; Sino Biological, USA) was determined after immobilizing the receptor on CM5 sensor chips. Immobilization on the carboxymethyl dextran-coated CM5 sensor chips was performed by using standard amine coupling chemistry to obtain an immobilization level of $\sim 200$ RU. Samples of adalimumab at $62.5 \mathrm{nM}, 125 \mathrm{nM}, 250 \mathrm{nM}, 500 \mathrm{nM}, 1,000 \mathrm{nM}$, and 2,000 $\mathrm{nM}$ concentrations were injected at a flow rate of $30 \mu \mathrm{L} /$ minute for 180 seconds. For dissociation of adalimumab from the receptor site, PBS-P+ buffer (phosphate buffer, $\mathrm{NaCl}, \mathrm{KCl}$, and Surfactant P20 from GE Healthcare Life Sciences) was injected at $30 \mu \mathrm{L} /$ minute for 300 seconds. Biacore T200 evaluation software (version 1.0) was used to determine $k_{d}$ and $k_{a}$ values.

\section{$r-H u T N F-\alpha$ neutralizing activity}

r-Hu-TNF- $\alpha$ (Sigma) neutralizing activity of adalimumab was performed on murine L929 cells (ATCC [American Type Culture Collection], Manassas, VA, USA; Cat No CCL-1) following a modified method described in literature. ${ }^{14} \mathrm{~L} 929$ cells were cultured overnight $\left(37^{\circ} \mathrm{C}\right)$ on 96 -well plates. Prior to addition to the cell plate, a series of diluted originator HUMIRA ${ }^{\circledR}$ or ZRC-3197 samples were prepared in the presence of fixed (optimized) amounts of TNF- $\alpha$ and actinomycin D to allow neutralization to take place for 60 minutes at $37^{\circ} \mathrm{C}$. After neutralization, $100 \mu \mathrm{L}$ of test sample mixture (ZRC-3197 or HUMIRA $^{\circledR}$ ) were withdrawn and transferred to the multiwells cell plate. Cell plates were further incubated at $37^{\circ} \mathrm{C}$ for 24 hours. At the end of incubation, TNF-neutralizing activity was estimated by a MTT, or 3-(4,5-dimethylthiazol-2-yl)-2,5diphenyltetrazoliumbromide, reduction assay. Results obtained as percent of cell viability (absorbance at $570 \mathrm{~nm}$ ) were plotted against different concentrations $(\mathrm{ng} / \mathrm{mL})$ of samples applied in a four-parameter sigmoidal dose-response curve by using GraphPad Prism software. TNF- $\alpha$ neutralizing activity of ZRC-3197 was expressed as a relative potency with respect to the originator HUMIRA ${ }^{\circledR}$. 


\section{Results and discussion}

ZRC-3197, a biosimilar of originator HUMIRA ${ }^{\circledR}$, was produced in genetically engineered $\mathrm{CHO}$ cells harboring the heavy-chain and light-chain genes of adalimumab (DE27). Upstream $\mathrm{CHO}$ cell culture process was performed with serum-free media in fed-batch mode in a bioreactor. $\mathrm{CHO}$ cell culture process in the bioreactor was conducted in a well-controlled manner in order to obtain highly biosimilar adalimumab, compared to that of the originator HUMIRA ${ }^{\circledR}$. During the cell culture process, certain key quality attributes of adalimumab were maintained by controlling the $\mathrm{pH}$, temperature, oxygen transfer rate, speed of agitation, and feeding of various nutrients and additives. Feeding of certain amino acid(s) appeared to be very critical to maintain the glycan profile of adalimumab as close as possible to that of the originator HUMIRA ${ }^{\circledR}$ product. The cell culture process, during production phase, was also monitored and controlled tightly from on a day-to-day basis for terminal Lys-heterogeneity on the heavy chains of adalimumab in order to produce a highly biosimilar ZRC-3197, compared to that of the originator HUMIRA $^{\circledR}$. Following upstream production, ZRC-3197 was purified by a three-step column chromatography process comprising Protein A affinity, hydrophobic interaction, and anion exchange column chromatography, in combination with membrane ultrafiltration-diafiltration and orthogonal viral inactivation (low $\mathrm{pH}$ ), and virus clearance (nano-filtration) steps.
Downstream process efficiency was established adequately for the removal of process-related impurities, like host cellderived contaminating proteins and DNA. The residual levels of process-related impurities were found to be very low in ZRC-3197 preparations, which complies with the regulatory guidelines (WHO and EMA) for biopharmaceuticals. At the end of purification, bulk drug substance of ZRC-3197 was prepared in succinate buffer of $\mathrm{pH} 5.2$ and containing sufficient amounts of sodium chloride, L-arginine, sorbitol, and polysorbate 80 , at $50 \mathrm{mg} / \mathrm{mL}$, by ultrafiltration-diafiltration. In the presence of specified inactive ingredients, ZRC-3197 has been found to remain stable for at least 24 months, under frozen or liquid form (refrigerated) in suitable containers with appropriate closure systems. Frozen bulk drug substance at the specified concentration was found to withstand at least ten cycles of freezing and thawing without any changes in physical appearance, protein concentration, purity, charge property, glycan profile, or TNF-neutralizing activity. For preparation of the drug product ZRC-3197, liquid bulk drug substance was directly filled in pre-filled syringes following the current Good Manufacturing Practices. The drug product of ZRC-3197 in pre-filled syringes were found to remain stable for at least 24 months, when stored under refrigerated conditions (between $2^{\circ} \mathrm{C}$ and $8^{\circ} \mathrm{C}$ ).

To demonstrate biosimilarity, drug product preparation of ZRC-3197 containing biosimilar adalimumab was

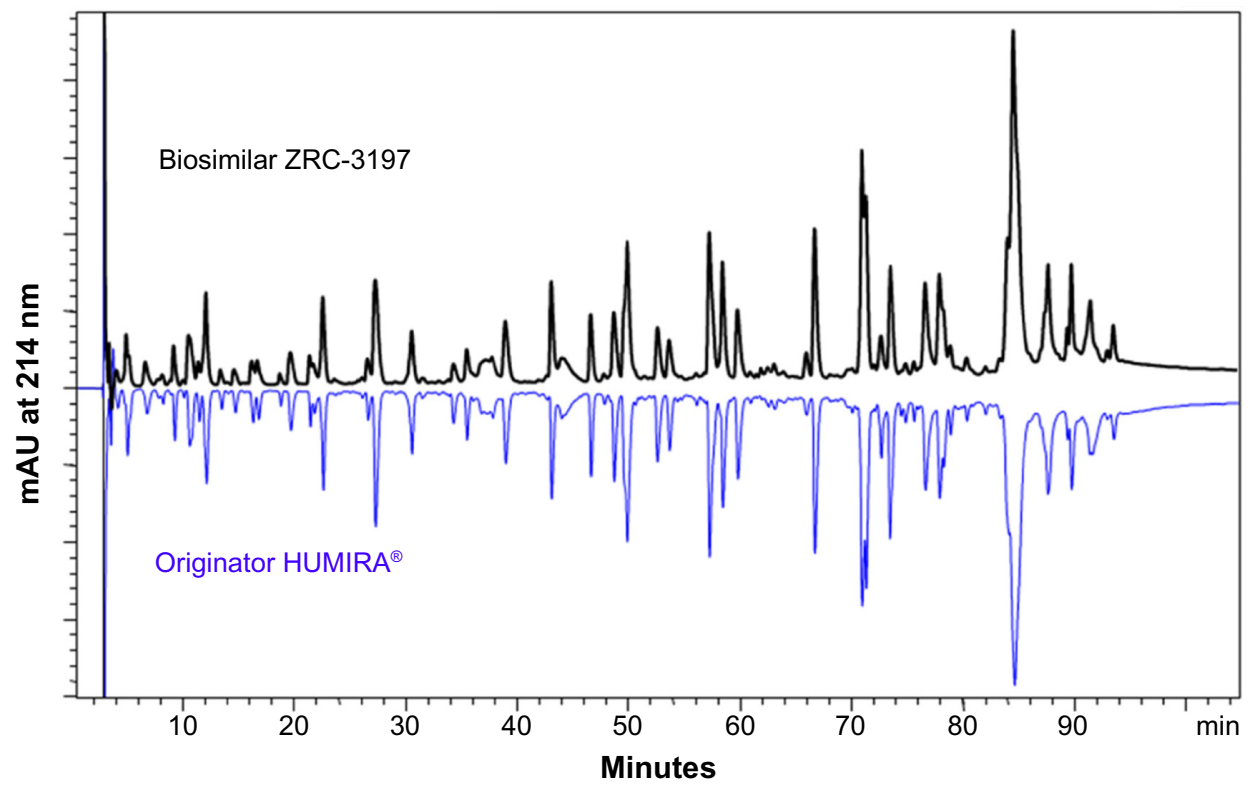

Figure I Comparison of the tryptic maps of the biosimilar ZRC-3197 and originator HUMIRA ${ }^{\circledast}$ by RP-HPLC-UV method. Samples containing $200 \mu$ g adalimumab were reduced and alkylated in the presence of a non-ionic detergent, at $\mathrm{pH}$ 8.0. Reduced-alkylated samples were digested with TPCK-trypsin to generate the peptide fragments. Tryptic digest obtained from the biosimilar ZRC-3197 or originator HUMIRA ${ }^{\circledast}$ was applied to CI8-RP-HPLC and separation of the peptide fragments was carried out with a gradient of trifluoroacetic acid and acetonitrile at a flow rate of $\mathrm{I} \mathrm{mL} / \mathrm{min}$ with UV detection $(214 \mathrm{~nm})$.

Abbreviations: UV, ultraviolet light; RP-HPLC, reverse-phase high-performance liquid chromatography; RP-HPLC-UV, RP-HPLC with UV; TPCK, L-(tosylamido-2-phenyl) ethyl chloromethyl ketone; min, minute; mAU, milli absorbance units. 
Table I Summary of the results of mass analysis by MALDITOF-TOF-MS: comparison between the biosimilar ZRC-3197 and originator HUMIRA ${ }^{\circledR}$

\begin{tabular}{llll}
\hline Samples & $\begin{array}{l}\text { Intact mass } \\
(\mathbf{k D a})\end{array}$ & $\begin{array}{l}\text { Heavy-chain } \\
\text { mass } \mathbf{( k D a )}\end{array}$ & $\begin{array}{l}\text { Light-chain } \\
\text { mass }(\mathbf{k D a})\end{array}$ \\
\hline Originator HUMIRA $^{\circledR}$ & 148.3 & 50.5 & 23.2 \\
Biosimilar ZRC-3197 & 148.3 & 50.5 & 23.2 \\
\hline
\end{tabular}

Notes: For intact mass analysis, samples containing adalimumab were desalted and mixed with sinapic acid matrix. The mixture was dried on a MALDI target prior to analysis in linear mid-mass positive mode. Molecular masses of the biosimilar ZRC3197 and the originator HUMIRA ${ }^{\circledast}$ were determined, separately, under non-reducing (intact) and reducing (heavy- and light-chain component) conditions. Under reduced condition, the heavy- and light-chain components of adalimumab were separated by RP-HPLC prior to analysis by ABI 4800 MALDI-TOF-TOF-MS.

Abbreviations: MALDI, matrix-assisted laser desorption-ionization; MALDI-TOFTOF-MS, MALDI-tandem time-of-flight mass spectrometry; RP-HPLC, reversephase high-performance liquid chromatography.

characterized comprehensively for physiochemical and functional properties, in comparison with multiple lot/batch materials of originator HUMIRA ${ }^{\circledR}$, sourced directly either from US or EU markets. No significant batch-to-batch variations in physicochemical properties were observed between the originator HUMIRA ${ }^{\circledR}$ and biosimilar ZRC-3197.

\section{Characterization of physicochemical properties}

\section{Primary structure and molecular identity}

Primary amino acid sequence analysis of the peptide fragments of adalimumab samples were carried out under various experimental conditions by LC-MS-MS and MALDI-TOF-MS, as described in the "Materials and methods" section. The overall amino acid sequences obtained for the heavy- and light-chain components of ZRC-3197 were found to be identical to the sequences obtained with originator HUMIRA ${ }^{\circledR}$, when analyzed under the same conditions, and the sequences were observed to be in good agreement with the reported sequence of D2E7. No detectable sequence variants were observed between the two products. Tryptic maps of the biosimilar ZRC-3197 by RP-HPLC-UV method showed indistinguishable chromatograms of the fragmented peptides from the originator HUMIRA $^{\circledR}$, when analyzed under the same conditions and illustrated in Figure 1. The N-terminal tryptic peptide of the heavy chain (EVQLVESGGGLVQPGR) of adalimumab was identified identically from the LC-MS-MS analysis of the in-gel digests of the heavy-chain bands obtained either with ZRC-3197 or originator HUMIRA ${ }^{\circledR}$ samples, using IDA methodology. The ions observed in each MS-MS spectrum were compared to the theoretical $b$ - and y-ions generated by the expected peptide. The ions observed for $\mathrm{N}$-terminal tryptic peptide from ZRC-3197 and originator

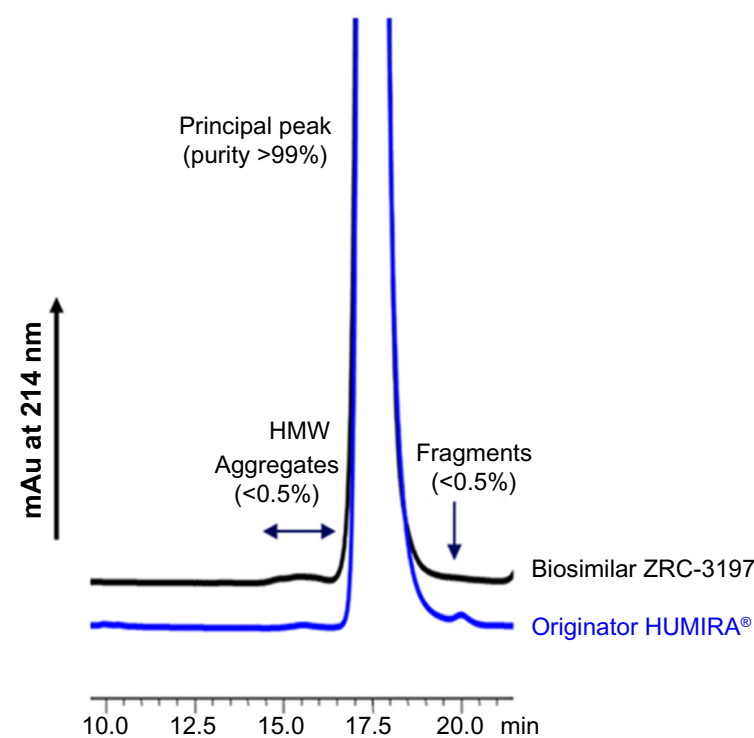

Figure 2 Purity of the biosimilar ZRC-3197 in comparison with the originator HUMIRA $^{\circledast}$ by HP-SEC analysis. Samples containing $10 \mu \mathrm{g}$ adalimumab from originator HUMIRA ${ }^{\circledast}$ or biosimilar ZRC-3197 preparation were injected onto an analytical TSK-G3000SWXL column and separation of different molecular weight species variants was carried out in an isocratic mode with a flow rate of $0.5 \mathrm{~mL} / \mathrm{min}$. Elution was monitored with UV detection at $214 \mathrm{~nm}$.

Abbreviations: HP-SEC, high-performance analytical size-exclusion chromatography; min, minute; UV, ultraviolet light; HMW, high molecular weight aggregates.

HUMIRA $^{\circledR}$ were $812.84(\mathrm{~m} / z ; z=2 ; \mathrm{RT}, 32.31$ minutes $)$ and $812.88(\mathrm{~m} / z ; z=2 ; \mathrm{RT}, 32.32$ minutes $)$, respectively. Similarly, the N-terminal tryptic peptide of the light chain (DIQMTQSPSSLSASVGDR) of adalimumab was identified from the LC-MS-MS analysis of the in-gel and in-solution
A

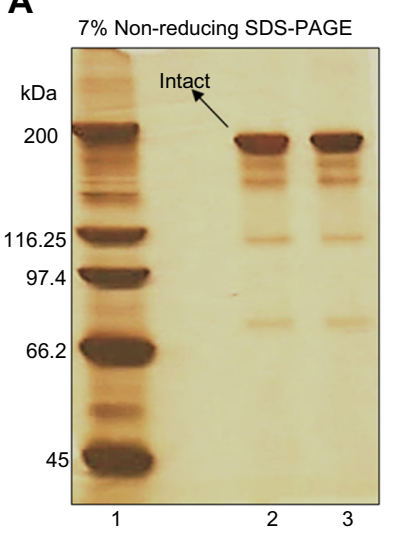

B

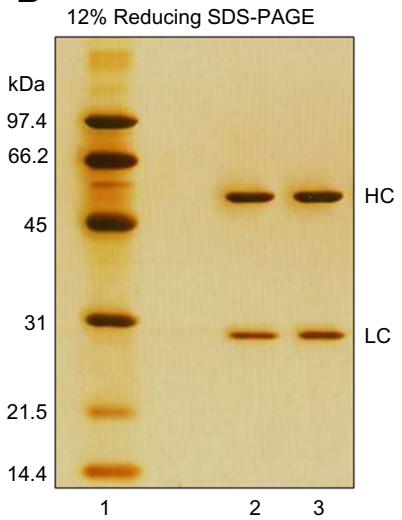

Figure 3 Comparison of the polypeptide profile of the biosimilar ZRC-3197 with respect to the originator HUMIRA ${ }^{\circledast}$ by SDS-PAGE analysis. Samples containing I $\mu \mathrm{g}$ adalimumab from the biosimilar ZRC-3197 (lane 3) or originator HUMIRA ${ }^{\circledast}$ (lane 2) preparation were analyzed by $7 \%$ and I $2 \%$ SDS-PAGE, under non-reducing (A) and reducing (B) conditions, respectively. Electrophoresis was carried out at constant current. Protein bands resolved on gel were developed by ammonical Ag-staining. (A) Non-reducing: lane I, high molecular weight protein markers (45-200 kDa). (B) Reducing: lane I, low molecular weight protein markers (I4.4-97.4 kDa); lane 2, originator HUMIRA ${ }^{\circledR}$; lane 3, biosimilar ZRC-3197.

Abbreviations: SDS-PAGE, sodium dodecyl sulfate polyacrylamide gel electrophoresis; LC, light chain; HC, heavy chain. 
tryptic digests of ZRC-3197 and originator HUMIRA ${ }^{\circledR}$. A targeted LC-MS-MS method was applied to obtain sequence confirmation, and the obtained sequences were found to be identical to each other. The C-terminal Lys-C peptide of the light chain (SFNRGEC) of adalimumab was identified from the LC-MS-MS analysis of the Lys-C digests of the lightchain bands of ZRC-3197 or originator HUMIRA ${ }^{\circledR}$ prepared from SDS-PAGE gels. The ions observed for C-terminal Lys-C peptide of ZRC-3197 and originator HUMIRA ${ }^{\circledR}$ were $435.18(\mathrm{~m} / \mathrm{z} ; \mathrm{z}=2$; RT, 8.32 minutes $)$ and $435.16(\mathrm{~m} / \mathrm{z} ; \mathrm{z}=2$; RT, 8.29 minutes), respectively, and found to be identical to each other. The C-terminal peptide of the heavy chain (HEALHNHYTQKSLSLSPGK) of adalimumab was identified from the LC-MS-MS analysis of the CNBr-digest of ZRC-3197 and originator HUMIRA ${ }^{\circledR}$. LC-MS chromatograms obtained with ZRC-3197 or originator HUMIRA ${ }^{\circledR}$ were observed to be identical to each other, and appeared to show mainly a C-terminal peptide without the terminal Lys $(\mathrm{K})$ residue, having a mass of 2,018 Da. No detectable difference was observed between the two products for C-terminal Lys-heterogeneity by MS analysis.

From a separate experiment, mass analysis of intact and reduced (heavy- and light-chain) forms of ZRC-3197 by MALDI-TOF-TOF-MS was observed to show identical molecular masses of adalimumab compared to that of the originator $\mathrm{HUMIRA}^{\circledR}$, when analyzed under the same conditions. The ion chromatograms obtained with the biosimilar ZRC-3197 were indistinguishable from the originator HUMIRA $^{\circledR}$, and no detectable additional ion species variants were observed to present with the biosimilar product as compared to that of the originator product. An intact single protonated centroid mass of $148.3\left(\mathrm{M}+\mathrm{H}^{+}\right) \mathrm{kDa}$ was obtained for both ZRC-3197 and originator HUMIRA ${ }^{\circledR}$, under native conditions. Under reduced conditions, masses obtained for the heavy $\left(\mathrm{M}+\mathrm{H}^{+} ; 50.5 \mathrm{kDa}\right)$ and light chains $\left(\mathrm{M}+\mathrm{H}^{+} ; 23.2 \mathrm{kDa}\right)$ of ZRC-3197 were also observed to be identical to the molecular masses of originator HUMIRA ${ }^{\circledR}$, shown in Table 1.

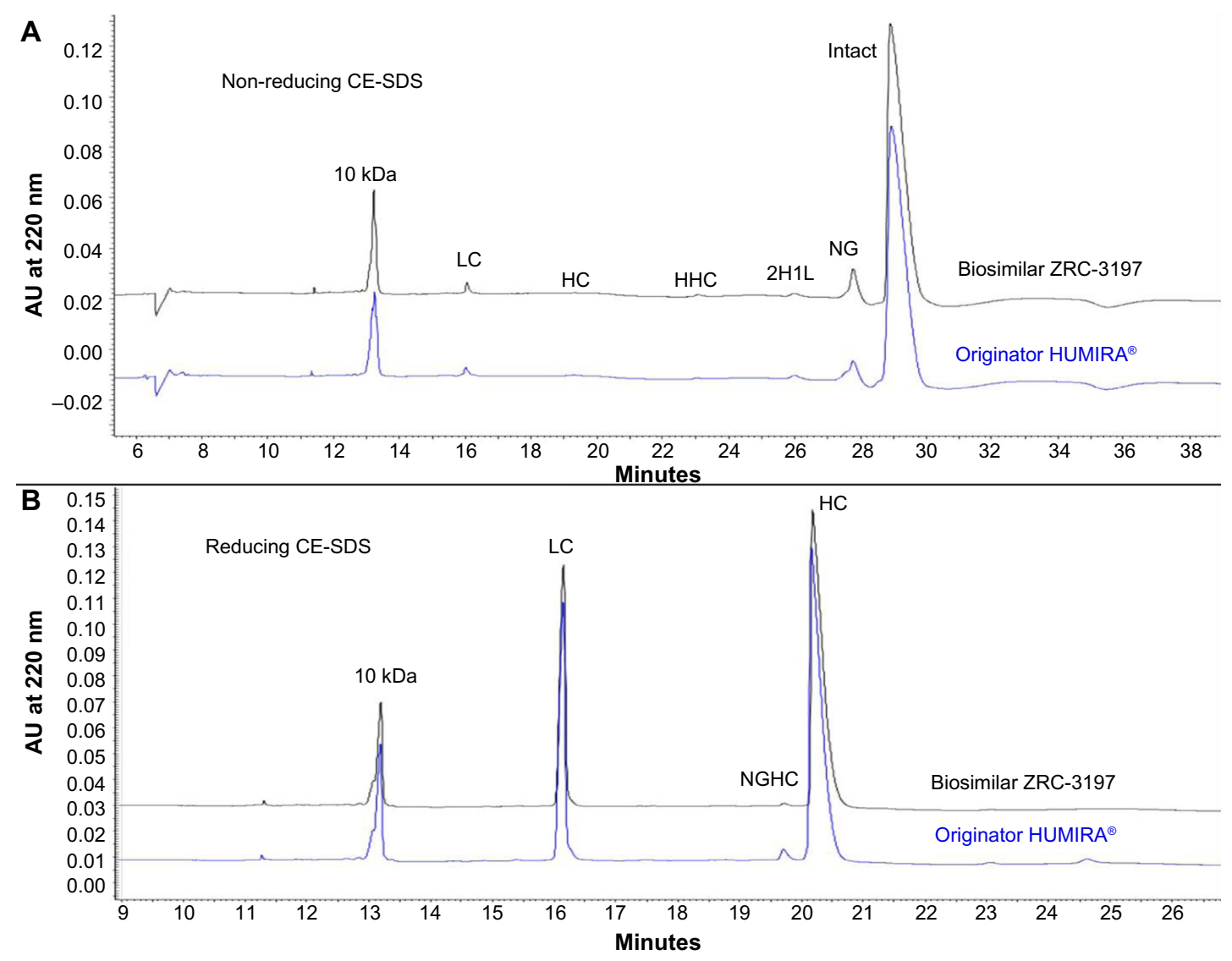

Figure 4 Comparison between the biosimilar ZRC-3I 97 and originator HUMIRA ${ }^{\circledR}$ for different size variants of adalimumab by CE-SDS. Samples at I mg/mL from originator HUMIRA $^{\circledast}$ or ZRC-3197 were analyzed by CE-SDS, under non-reducing $(\mathbf{A})$ and reducing (B) conditions, using an uncoated capillary on a Beckman PA800 Plus instrument. Non-reducing CE-SDS analysis was performed with alkylated samples, whereas reducing CE-SDS analysis was conducted with $\beta$-mercaptoethanol-treated samples. For system suitability, an internal standard of $10 \mathrm{kDa}$ MW marker was mixed with each sample before analysis. Separation was monitored at $220 \mathrm{~nm}$ with PDA detection.

Abbreviations: CE-SDS, sodium dodecyl sulfate capillary electrophoresis; LC, light chain; HC, heavy chain; HHC, heavy-heavy chains; $2 \mathrm{HIL}$, two heavy chains with one light chain; NG, non-glycosylated; NGHC, non-glycosylated heavy chain; PDA, photodiode array; MW, molecular weight. 


\section{Purity and molecular integrity}

Purity of the biosimilar ZRC-3197 was assessed by a set of orthogonal analytical methods on the basis of molecular sizes and compared with the originator HUMIRA ${ }^{\circledR}$, under the same conditions. In HP-SEC analysis, the biosimilar ZRC-3197 preparation was observed to show a similar level of purity, as compared to that of the originator HUMIRA ${ }^{\circledR}$, comprising more than $99 \%$ of the monomeric form of adalimumab and less than $0.5 \%$ high molecular weight (HMW) aggregates, under native condition.

No detectable amount of fragmented low molecular weight variant was observed in the biosimilar preparation, which was otherwise observed to be present, consistently, in the originator product shown in Figure 2. Both biosimilar ZRC-3197 and originator HUMIRA ${ }^{\circledR}$ were observed to elute at the same retention time in the chromatograms, indicating that the two products share a hydrodynamic size in common with adalimumab.

Denaturing SDS-PAGE analysis under non-reducing and reducing conditions showed indistinguishable polypeptide profile of the biosimilar ZRC-3197 from the originator HUMIRA $^{\circledR}$. Figure $3 \mathrm{~A}$ and B illustrate a comparative polypeptide profile of the two products by non-reducing and reducing SDS-PAGE and stained with Ag-solution. Like the originator HUMIRA ${ }^{\circledR}$ (lane 2), the biosimilar ZRC-3197 (lane 3) exhibited a number of minor size variants, which moved faster (low molecular weight) than the principal band of adalimumab in gel, under non-reducing conditions (Figure 3A). No detectable differences in terms of electrophoretic mobility and band intensity of the fast-moving minor bands were observed between the two products. Under reducing conditions (Figure 3B), both biosimilar ZRC-3197 and originator HUMIRA ${ }^{\circledR}$ were resolved on gel, mainly with the heavy- and light-chain components, as expected. Intensity and electrophoretic mobility of the bands resolved on gel were analytically indistinguishable, when compared to each other. No additional molecular size variants or detectable HMW variants were observed with the biosimilar ZRC-3197 (lane 3 ) as compared to those of the originator HUMIRA ${ }^{\circledR}$ (lane 2) by SDS-PAGE.

Similar to the SDS-PAGE analysis, non-reducing CE-SDS analysis of biosimilar ZRC-3197 and originator HUMIRA ${ }^{\circledR}$ also revealed the presence of a set of minor low molecular weight size variants of adalimumab in the preparations. Electropherograms obtained with the biosimilar and the originator products were indistinguishable when compared with each other, as shown in Figure 4A. In the electropherograms, both biosimilar ZRC-3197 and HUMIRA ${ }^{\circledR}$ showed more than $92 \%$ purity of the principal variant of adalimumab. The other minor variants were observed to be present at very low levels, for example: free LC, approximately $1 \%$; free $\mathrm{HC}$, $<0.1 \%$; HHC,$<0.5 \%$; $2 \mathrm{H} 1 \mathrm{~L},<1 \%$; and NG, $5 \%-6 \%$. No HMW size variants were detected in the electropherograms of the two products. Similarly, reducing CE-SDS analysis of the biosimilar ZRC-3197 and originator HUMIRA ${ }^{\circledR}$ appeared to show indistinguishable distribution pattern of adalimumab components in electropherograms, as shown in Figure 4B. However, the NGHC content in the biosimilar ZRC-3197 was observed to be $<1 \%$, whereas the NGHC content was approximately $1.3 \%$ in the originator HUMIRA ${ }^{\circledR}$.

\section{Heterogeneity of charged species variants}

Differently charged species variants of adalimumab present in biosimilar ZRC-3197 or originator HUMIRA ${ }^{\circledR}$ were assessed on a comparative basis by two different orthogonal analytical methods - analytical HP-IEC and cIEF. The HPIEC was used for the separation and quantification of different HC-K (Lys) species variants (basic isoforms) and acidic variants (deamidated and sialylated isoforms) of adalimumab. Figure 5 illustrates the charged variants profile of biosimilar

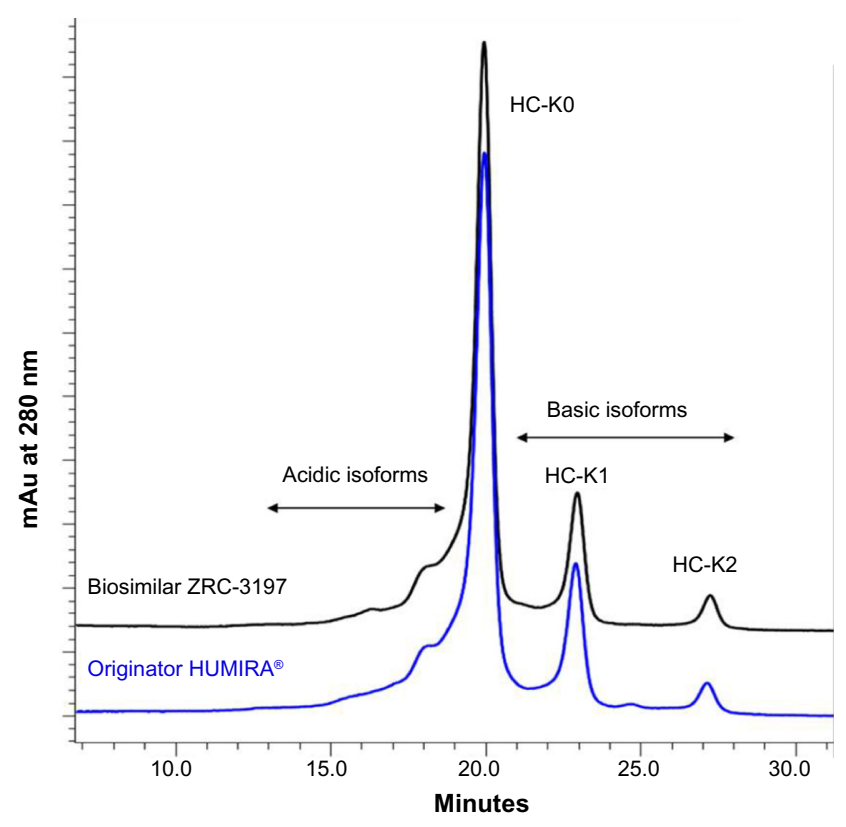

Figure 5 Comparison of the charge heterogeneity profile of the biosimilar ZRC3197 with respect to the originator HUMIRA ${ }^{\circledast}$ by HP-IEC. Samples containing $50 \mu \mathrm{g}$ adalimumab from originator HUMIRA ${ }^{\circledR}$ or ZRC-3 197 preparation were injected onto a TSK-Gel CM-STAT weak cation-exchange column equilibrated with phosphate buffer of $\mathrm{pH} 6.9$ containing $\mathrm{NaCl}$. Separation of the charged species variants was performed with a linear salt gradient at a flow rate of $\mathrm{I} \mathrm{mL} / \mathrm{min}$, and elution was monitored at $280 \mathrm{~nm}$ with UV detection.

Abbreviations: Lys, lysine; HC-KO, heavy chain with no terminal Lys; HC-KI, heavy chain with one terminal Lys; HC-K2, heavy chain with two terminal Lys; HP-IEC, high-performance analytical ion exchange chromatography; min, minutes; UV, ultraviolet light. 
ZRC-3197 and originator HUMIRA ${ }^{\circledR}$, on a comparative basis, as assessed by HP-weak cation exchange chromatography. As evident in Figure 5, the biosimilar ZRC-3197 was observed to show a high degree of sameness of charged variants profile as that of the originator product. In the chromatogram, the biosimilar ZRC-3197 was observed to contain approximately 9\% total acidic isoforms, 75\% main HC-K0 (no Lys) variant, and approximately $17 \%$ total basic isoforms, which was in good agreement with the results obtained with multiple lot/ batch materials of originator HUMIRA ${ }^{\circledR}$. One of the basic isoforms that appeared between the $\mathrm{HC}-\mathrm{K} 2$ and $\mathrm{HC}-\mathrm{K} 1$ variants of the originator product was not detected in the biosimilar preparation, when analyzed under the same conditions.

Further, a comparative analysis of differently charged species variants of ZRC-3197 and originator HUMIRA ${ }^{\circledR}$ were assessed on the basis of $\mathrm{pI}$ values by cIEF, as shown in Figure 6. Differently charged species variants of biosimilar ZRC-3197 and originator HUMIRA ${ }^{\circledR}$ were observed to focus in the $\mathrm{pI}$ range of 9.0 (basic) to 8.2 (relatively acidic), as indicated in the Figure 6. An identical pI value of approximately 8.7 was obtained for the main species variant of the two products. Consistent with the HP-IEC results, no significant differences were observed in the cIEF chromatograms obtained with the biosimilar ZRC-3197 and originator HUMIRA ${ }^{\circledR}$, indicating a high level of sameness of charge heterogeneity profile between the two products.

\section{Carbohydrate structure analysis}

Figure 7 illustrates the UHPLC chromatograms of 2-ABlabeled glycans obtained with the biosimilar ZRC-3197 and originator HUMIRA ${ }^{\circledR}$. Different glycan species extracted from the biosimilar ZRC-3197 or from the originator product were identified, with respect to a standard glycan library, and quantified chromatographically. It is clear from Figure 7 that carbohydrate structure of adalimumab, predominantly, is comprised of G0F. Among the lowabundant (1\%-15\%) glycans, G0F-N, G0, Man5, G1F/ G1'F, and G2F moieties were observed to be present in both ZRC-3197 and the originator product. Very low levels ( $\leq 1 \%$ ) of other glycans, such as G0FB, G1, G1FB, Man6, G2, G1FS1, and A1F were also detected in both preparations of adalimumab. No significant difference in the content of afucosylated glycans was found between the two products. Biosimilar ZRC-3197 showed slightly lower amounts of Man5 (1.19\%) as compared to that of the originator HUMIRA ${ }^{\circledR}(3.75 \%)$. A summary of the results

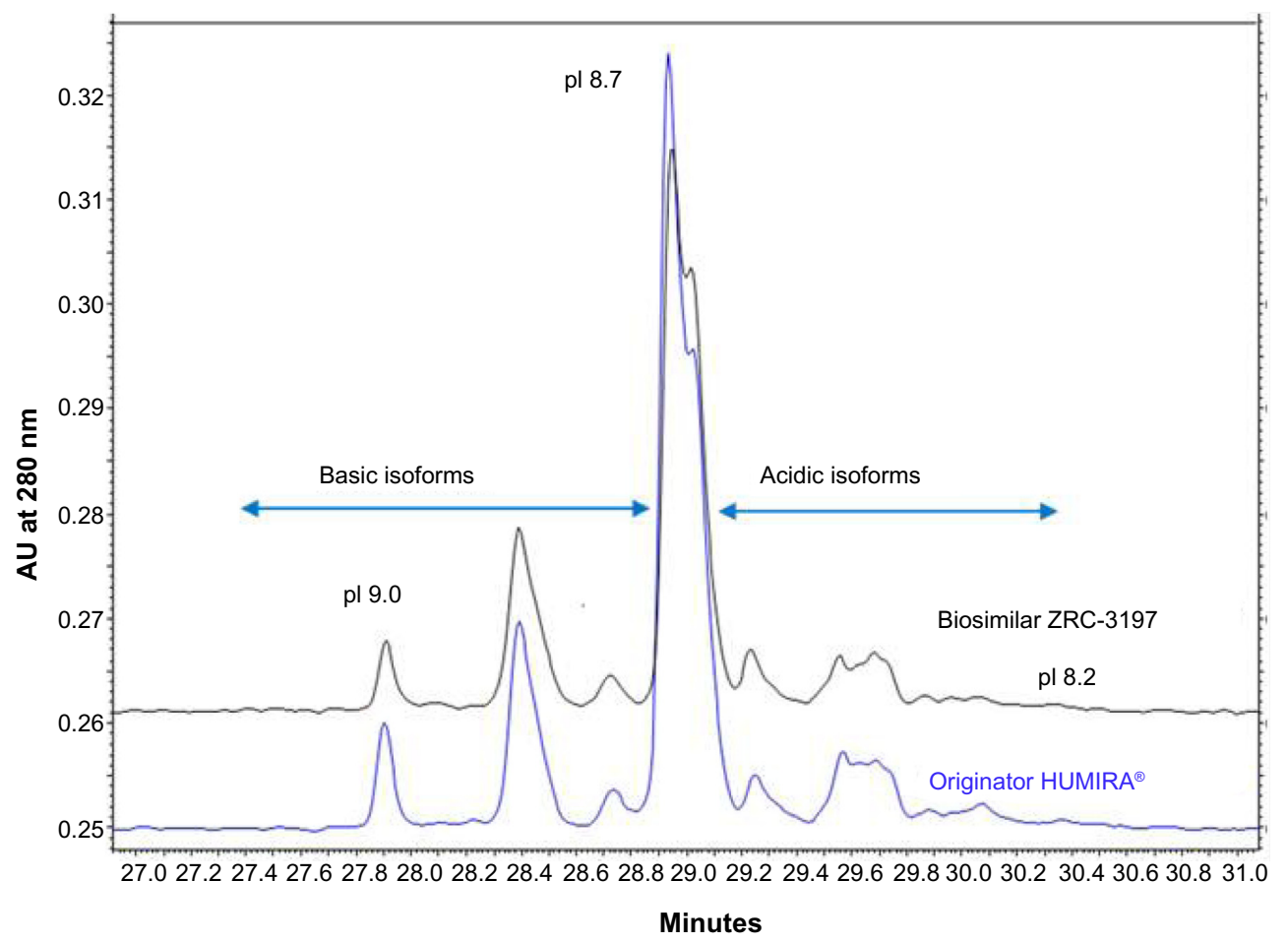

Figure 6 Comparison of the charge heterogeneity profile of the biosimilar ZRC-3197 with respect to the originator HUMIRA ${ }^{\circledR}$ by cIEF. Samples at 0.2 mg/mL were mixed with a master mix containing urea-clEF gel, pharmalyte ${ }^{\circledR}$ (three to ten ampholytes, cathodic and anodic stabilizers, and a known pl marker (supplied by Beckman Coulter Inc., Pasadena, CA, USA), and pressure-injected onto a neutral-coated eCAP TM capillary. After pre-focusing at $25 \mathrm{kV}$ for 15 minutes, samples were focused at $30 \mathrm{kV}$ for 30 minutes. Separation was monitored at $280 \mathrm{~nm}$ with UV detection. pl values were determined with respect to the known pl calibration markers, pl I0, pl 7.0, and pl 4.I.

Abbreviations: cIEF, capillary isoelectric focusing; pl, isoelectric point; eCAP, amine capillary with laser burned window; UV, ultraviolet light. 


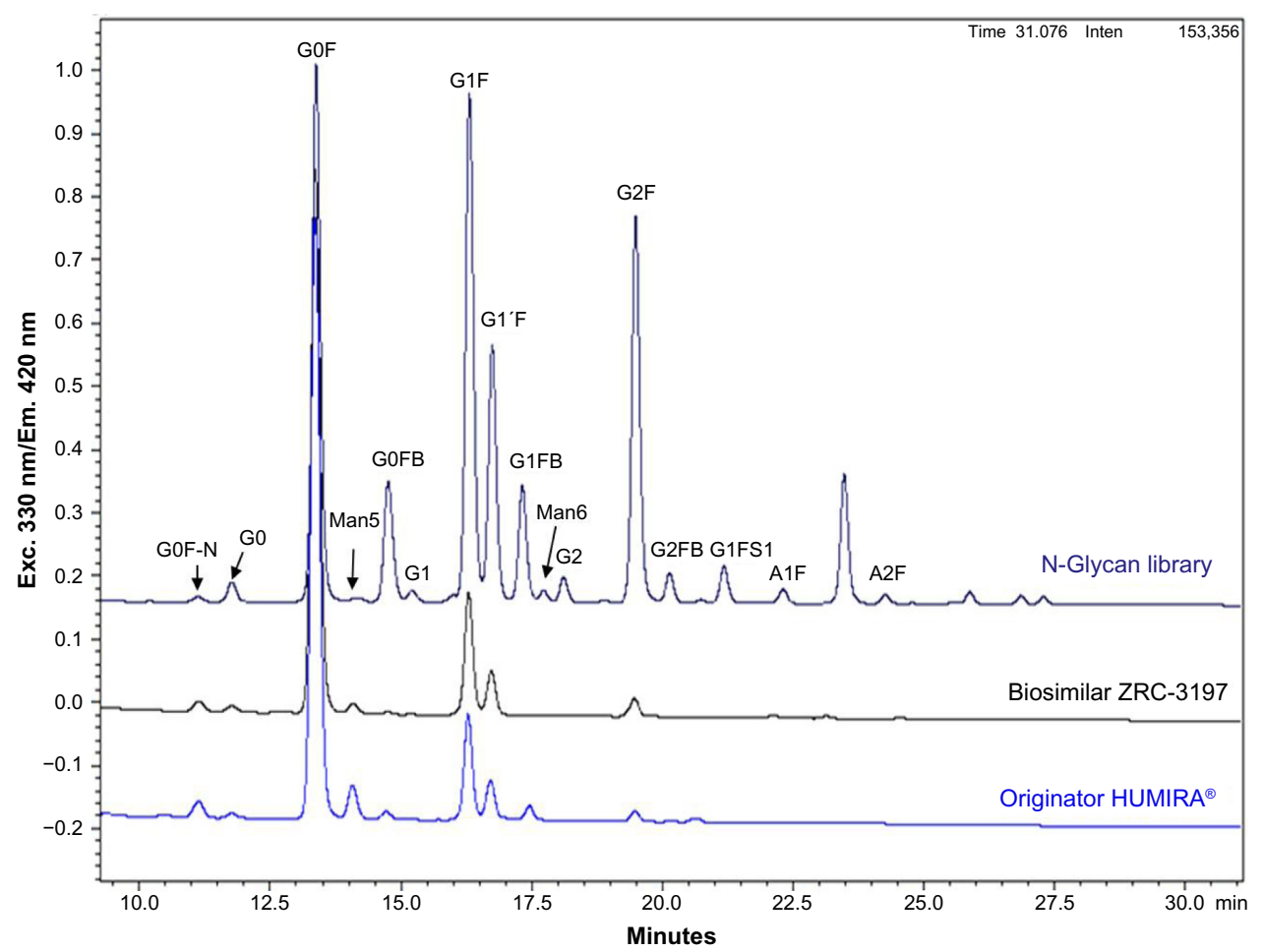

Figure 7 Comparison of the glycan profile of the biosimilar ZRC-3197 with respect to the originator HUMIRA ${ }^{\circledR}$ by UHPLC method. Samples $\left(\right.$ ZRC-3।97 or HUMIRA $\left.{ }^{\circledR}\right)$ containing $300 \mu \mathrm{g}$ adalimumab were treated with PNGase to extract the glycan moieties. After extraction, the glycan moieties were labeled with 2-AB dye. The labeled glycans were separated by UHPLC. Elution of glycans was monitored by fluorescence detection with excitation at $330 \mathrm{~nm}$ and emission at $420 \mathrm{~nm}$. Different types of glycans obtained from the samples were identified with respect to the known glycan standards analyzed under the same conditions.

Abbreviations: UHPLC, ultra-high-performance liquid chromatography; 2-AB, 2-aminobenzamide; G0F-N, asialo-agalacto-fucosylated without one N-acetylglucosamine biantennary; G0, asialo-agalacto biantennary; G0F, asialo-agalacto-fucosylated biantennary; Man5, oligomannose 5; G0FB, asialo-agalacto-fucosylated biantennary with bisecting $\mathrm{N}$-acetylglucosamine; GI, asialo-monogalactosylated biantennary; GIF/GI'F, asialo-monogalactosylated (I and I')-fucosylated biantennary isoforms; GIFB, asialomonogalactosylated-fucosylated biantennary with bisecting $\mathrm{N}$-acetylglucosamine; Man6, oligomannose 6; G2, asialo-galactosylated biantennary; G2F, asialo-galactosylatedfucosylated biantennary; G2FB, asialo-galactosylated-fucosylated biantennary with bisecting $\mathrm{N}$-acetylglucosamine; GIFSI, monosialylated-monogalactosylated-fucosylated biantennary; AIF, monosialylated-galactosylated-fucosylated biantennary; A2F, disialylated-galactosylated-fucosylated biantennary; Exc, excitation; Em, emission.

on various glycan species obtained with the two products has been shown in Table 2. Overall pattern and abundance of various glycan moieties obtained with the biosimilar ZRC-3197 were observed to show high level of sameness with the originator HUMIRA ${ }^{\circledR}$.

When analysed by HPAEC-PAD, the biosimilar ZRC-3197 was observed to show highly similar levels of monosaccharides contents in comparison with the originator product. A summary of the results obtained for monosaccharides has been shown in Table 3. The lower limit of quantification for all monosaccharides in the sample was considered to be $12.5 \mu \mathrm{g} / \mathrm{mL}$, based on the lowest concentration of standard analyzed. The glycan components of both samples were found to be predominantly composed of fucose, glucosamine, and mannose. On the other hand, relatively low levels of galactosamine and galactose were detected in both ZRC-3197 and originator HUMIRA $^{\circledR}$ when analyzed under the same conditions, as shown in Table 3.

\section{Secondary structure analysis}

Secondary structure analysis of the biosimilar ZRC-3197 and originator HUMIRA ${ }^{\circledR}$ was conducted by CD spectroscopy in the far-UV (250-190 $\mathrm{nm}$ ) region to assess the folding pattern of protein on a comparative basis. As illustrated in Figure 8, CD spectra obtained with the biosimilar ZRC-3197 and originator HUMIRA ${ }^{\circledR}$ were shown to overlap with each other in the far-UV region. The overlapping CD spectra obtained with both products showed an absorbance minimum in the wavelength range of $216-218 \mathrm{~nm}$, which indicated the presence of predominant beta-structures in adalimumab.

Further, higher order structure of the biosimilar ZRC3197 and originator HUMIRA ${ }^{\circledR}$ was assessed through disulfide bridge mapping by LC-MS-MS and MALDITOF-MS. The following $\mathrm{S}-\mathrm{S}$ bridges were identified: 1) intrachain, including LC variable region [Cys(L23)Cys(L88); LC constant region Cys(L134)-Cys(L194); $\mathrm{HC}$ variable region [Cys(H22)-Cys(H96); HC constant (CH1) region Cys(H148)-Cys(H204); HC constant (CH2) 
Table 2 Relative distributions of different glycan species variants of adalimumab obtained with the biosimilar ZRC-3197 and originator HUMIRA ${ }^{\circledR}$ by UHPLC method

\begin{tabular}{lll}
\hline $\begin{array}{l}\text { Glycan } \\
\text { variants }\end{array}$ & \multicolumn{2}{l}{ \% Relative distribution of glycan variants } \\
\cline { 2 - 3 } & Originator HUMIRA & Biosimilar ZRC-3 I97 \\
\hline G0F-N & 2.27 & 1.61 \\
G0 & 0.65 & 0.94 \\
G0F & 74.50 & 73.86 \\
Man5 & 3.75 & 1.20 \\
G0FB & 0.86 & 0.29 \\
GI & 0.04 & 0.06 \\
GIF & $11.1 I$ & 14.30 \\
GI'F & 3.74 & 4.81 \\
GIFB/Man6 & 1.49 & 0.15 \\
G2F & 1.31 & 2.27 \\
G2FB & 0.21 & 0.08 \\
AIF & 0.06 & 0.44 \\
\hline Notes
\end{tabular}

Notes: Fluorescence (2-aminobenzamide)-labeled glycan variants extracted from ZRC3197 and originator HUMIRA ${ }^{\circledast}$ were separated by UHPLC method. Distribution of each glycan species separated by the UHPLC method was calculated as a percentage of the individual peak area over the total peak area, using a LabSolutions computer software program. GIFB and Man6 have been shown together, since the chromatographic resolution of the peaks between the two species was not very prominent.

Abbreviation: UHPLC, ultra-high-performance liquid chromatography; GOF-N, asialo-agalacto-fucosylated without one $\mathrm{N}$-acetylglucosamine biantennary; G0, asialo-agalacto biantennary; GOF, asialo-agalacto-fucosylated biantennary; Man5, oligomannose 5; GOFB, asialo-agalacto-fucosylated biantennary with bisecting $\mathrm{N}$-acetylglucosamine; GI, asialo-monogalactosylated biantennary; GIF/GI'F, asialomonogalactosylated ( $I$ and $\left.I^{\prime}\right)$-fucosylated biantennary isoforms; GIFB, asialomonogalactosylated-fucosylated biantennary with bisecting $\mathrm{N}$-acetylglucosamine; Man6, oligomannose 6; G2, asialo-galactosylated biantennary; G2F, asialogalactosylated-fucosylated biantennary; G2FB, asialo-galactosylated-fucosylated biantennary with bisecting $\mathrm{N}$-acetylglucosamine; $\mathrm{AIF}$, monosialylated-galactosylatedfucosylated biantennary.

region $[\mathrm{Cys}(\mathrm{H} 265)-\mathrm{Cys}(\mathrm{H} 325)$; $\mathrm{HC}$ constant $(\mathrm{CH} 3)$ region [Cys(H371)-Cys(H429)]; and 2) interchain, including between HC-LC [Cys(H224)-Cys(L214); between HC-HC [Cys(H230)-Cys(H230); and between HC-HC [Cys(H233)Cys(H233)]. No mismatched disulfide bonds were detected

Table 3 Comparison of monosaccharide contents between the biosimilar ZRC-3197 and originator HUMIRA ${ }^{\circledR}$

\begin{tabular}{lll}
\hline Monosaccharides & $\begin{array}{l}\text { Concentration of } \\
\text { monosaccharides }(\mu \mathrm{g} \text { sugar } / \mathrm{mL} \\
\text { protein sample) }\end{array}$ \\
\cline { 2 - 3 } & $\begin{array}{l}\text { Originator } \\
\text { HUMIRA }\end{array}$ & $\begin{array}{l}\text { Biosimilar } \\
\text { ZRC-3 I97 }\end{array}$ \\
\hline Fucose & 97 & 105 \\
Galactosamine & $<12.5^{*}$ & $<12.5^{*}$ \\
Glucosamine & 389 & 374 \\
Galactose & 25 & 30 \\
Mannose & 297 & 311 \\
\hline
\end{tabular}

Notes: Neutral and amino sugars were extracted by acid hydrolysis of the adalimumab samples in the presence of trifluoroacetic acid at $100^{\circ} \mathrm{C}$ for 4 hours. Hydrolyzed samples were dried and reconstituted in deionized water before analysis. Extracted sugars were analyzed and quantified with respect to the known concentrations of standard monosaccharides by using the HPAEC-PAD system on Dionex system. *LOQ (lower limit of quantification) for all monosaccharides analyzed was $12.5 \mu \mathrm{g} / \mathrm{mL}$.

Abbreviation: HPAEC-PAD, high-performance anion exchange chromatography with pulsed amperometric detection. in originator product or the biosimilar ZRC-3197. In addition, free thiol estimation by DTNB assay did not show any significant presence of free thiol in either of the two products. A total number of free thiols obtained with both ZRC-3197 and originator HUMIRA ${ }^{\circledR}$ was in the range of 0.17-0.27 mol Cys $/ \mathrm{mol}$ of adalimumab, indicating that no free thiols were available in the protein structure.

\section{Post-translational modifications}

LC-MS-MS data from tryptic digests prepared by insolution digestion and in-gel digestion were searched (using MASCOT) against databases containing either the heavy- or light-chain sequences. Deamidation, oxidation, and phosphorylation were included in the search as permissible variable modifications. Low levels of oxidation and deamidation were detected in both biosimilar ZRC-3197 and originator HUMIRA $^{\circledR}$, although in all cases the peptides identified as containing the modifications were also identified without modification, indicating that the modifications were present in only a portion of the molecules. The number and locations of the modifications were generally consistent between the biosimilar ZRC-3197 and originator product. No detectable modifications were observed in the complementaritydetermining regions (CDRs) of ZRC-3197 and originator HUMIRA $^{\circledR}$.

No detectable methionine (Met) oxidation was observed on the light-chain component of the two products. Low level of Met-oxidation on a small population of heavychain molecules of biosimilar ZRC-3197 and originator HUMIRA $^{\circledR}$ was observed, mainly at the positions HC-Met ${ }^{83}$ and $\mathrm{HC}-\mathrm{Met}^{256}$.

Low levels of deamidation on a small population of light-chain and heavy-chain components of ZRC-3197 or originator product was observed at the positions $\mathrm{LC}-\mathrm{G} \ln ^{155}$, LC-Gln ${ }^{160}, \mathrm{LC}^{-A s n}{ }^{137}, \mathrm{HC}-\mathrm{Asn}^{77}, \mathrm{HC}-\mathrm{Asn}^{280}, \mathrm{HC}-\mathrm{Gln}{ }^{315}$, $\mathrm{HC}-\mathrm{Asn}^{319}, \mathrm{HC}-\mathrm{Asn}^{388}$, and HC-Gln ${ }^{390}$.

In both ZRC-3197 and originator HUMIRA ${ }^{\circledR}$ samples, the glycosylation site was confirmed at the position $\mathrm{Asn}^{301}$ on heavy-chain components.

No detectable phosphorylation was observed in ZRC3197 or originator HUMIRA ${ }^{\circledR}$.

\section{Functional properties}

\section{Affinity for TNF- $\alpha$ and FcyRllla receptor}

SPR technique was used to determine the affinity constants of ZRC-3197 and originator HUMIRA ${ }^{\circledR}$ to r-HuTNF- $\alpha$ and FcyRIIIa (CD16) receptor, separately, on a comparative basis. 


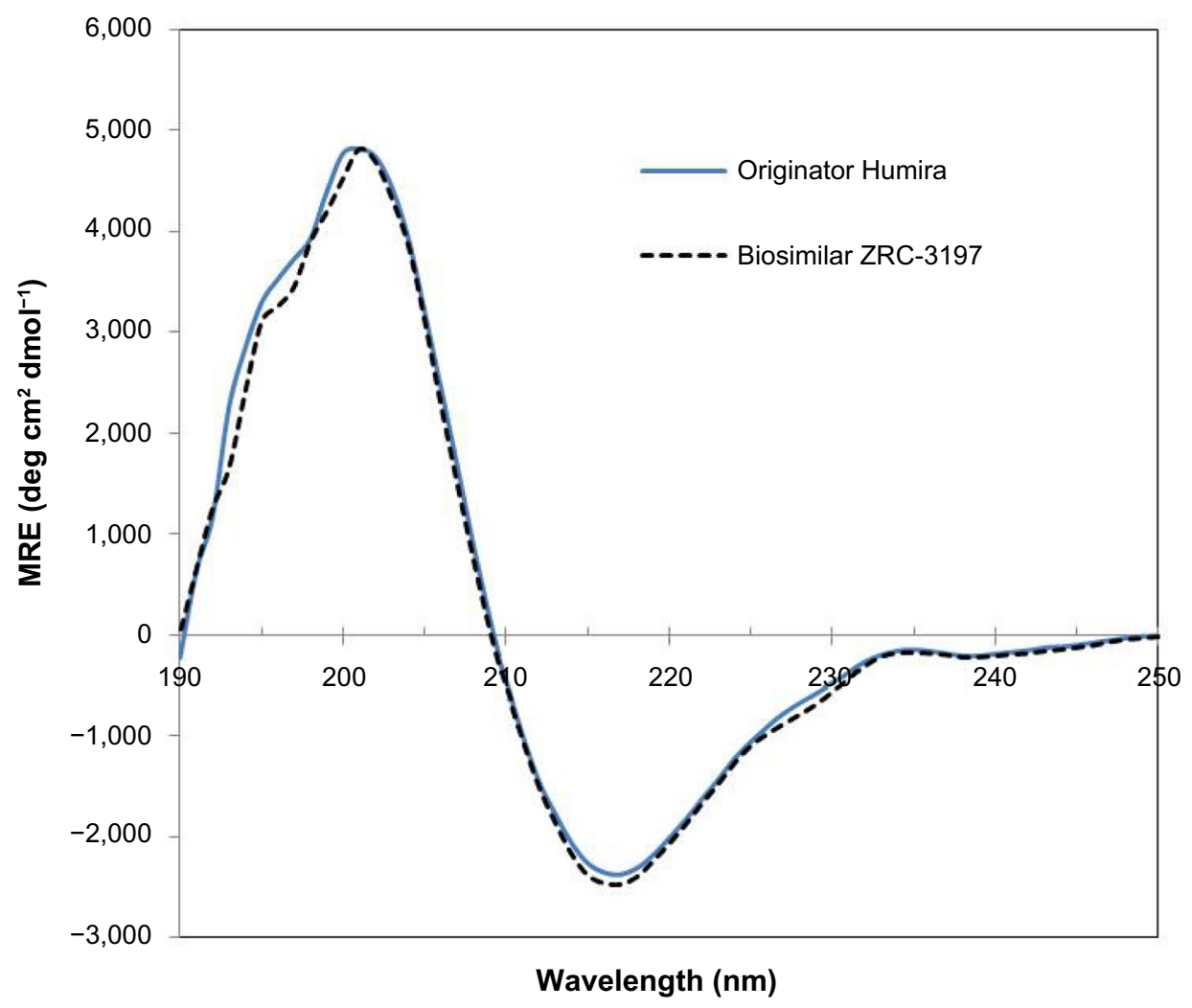

Figure 8 Comparison of the secondary structure of the biosimilar ZRC-3197 with respect to the originator HUMIRA ${ }^{\circledR}$ by CD spectroscopy. Samples from originator HUMIRA $^{\circledR}$ or biosimilar ZRC-3197 preparation, at $0.25 \mathrm{mg} / \mathrm{mL}$, were analyzed in the far-UV region (250-190 nm), under room temperature conditions by CD spectroscopy. Analysis was performed in the same buffer system at $\mathrm{pH}$ 5.2. Mean residue ellipticity (MRE; deg. $\mathrm{cm}^{2} \cdot \mathrm{dmol}^{-1}$ ) was calculated following a standard formula considering a molecular weight of I48 kDa (I330 amino acids) for adalimumab.

Abbreviations: $C D$, circular dichroism; UV, ultraviolet light.

It has been established unequivocally that adalimumab binds circulating TNF- $\alpha$ with high affinity and blocks its interaction with the receptors on cell surfaces. ${ }^{15}$ The crystal structure of TNF- $\alpha$ in complex with adalimumab Fab has revealed that adalimumab inhibits TNF- $\alpha$ by blocking the TNF-receptor binding site. ${ }^{16}$ Since the primary mechanism of action of adalimumab involves the binding of TNF- $\alpha$, it was highly important to determine the affinity of the biosimilar ZRC-3197 for TNF- $\alpha$ in comparison with the originator HUMIRA $^{\circledR}$, in parallel. Figure 9 illustrates the kinetics of TNF-adalimumab association and dissociation obtained with biosimilar ZRC-3197 and originator HUMIRA ${ }^{\circledR}$, separately, under the same experimental conditions. The calculated $\mathrm{KD}$ (equilibrium constant) value $\left(3.08 \times 10^{-10} \mathrm{M}\right)$ obtained with the biosimilar ZRC-3197 was observed to be indistinguishable from the KD value calculated for the originator HUMIRA ${ }^{\circledR}$ $\left(2.96 \times 10^{-10} \mathrm{M}\right)$. These results indicate that the two products have the same affinity for TNF- $\alpha$.

Since the Fc region of adalimumab is known to bind to Fc $\gamma$ receptors, primarily expressed on leukocytes, SPRbased binding assays were carried out to determine the affinity of ZRC-3197 and originator HUMIRA ${ }^{\circledR}$, in parallel, for recombinant human FcyRIIIa (or CD16) receptor, as illustrated in Figure 10. ${ }^{15,17,18} \mathrm{~A}$ KD value of $4.89 \times 10^{-7} \mathrm{M}$ of ZRC-3197 for the FcyRIIIa receptor was observed to be highly comparable with the KD value of $4.47 \times 10^{-7} \mathrm{M}$ of originator HUMIRA ${ }^{\circledR}$, as assessed by SPR technique on a Biacore T200 instrument.

\section{In vitro TNF-neutralizing activity}

Adalimumab binds to TNF- $\alpha$ and prevents its interaction with surface receptors on L929 cells, leading to a dose-dependent reduction in TNF-mediated killing of the L929 cells. An overlapping sigmoidal dose-response curve was obtained with both ZRC-3197 and originator HUMIRA ${ }^{\circledR}$. Half maximal effective concentration $\left(\mathrm{EC}_{50}\right)$ value calculated for ZRC-3197 from the dose-response curve was observed to be same as that of the originator HUMIRA ${ }^{\circledR}$, illustrated in Figure 11. With respect to the originator $\mathrm{HUMIRA}^{\circledR}$, a relative potency ratio of ZRC3197 was observed to be $100.4 \%$. These results, taken together, demonstrated the high level of sameness of functional properties of ZRC-3197 and the originator HUMIRA ${ }^{\circledR}$. 


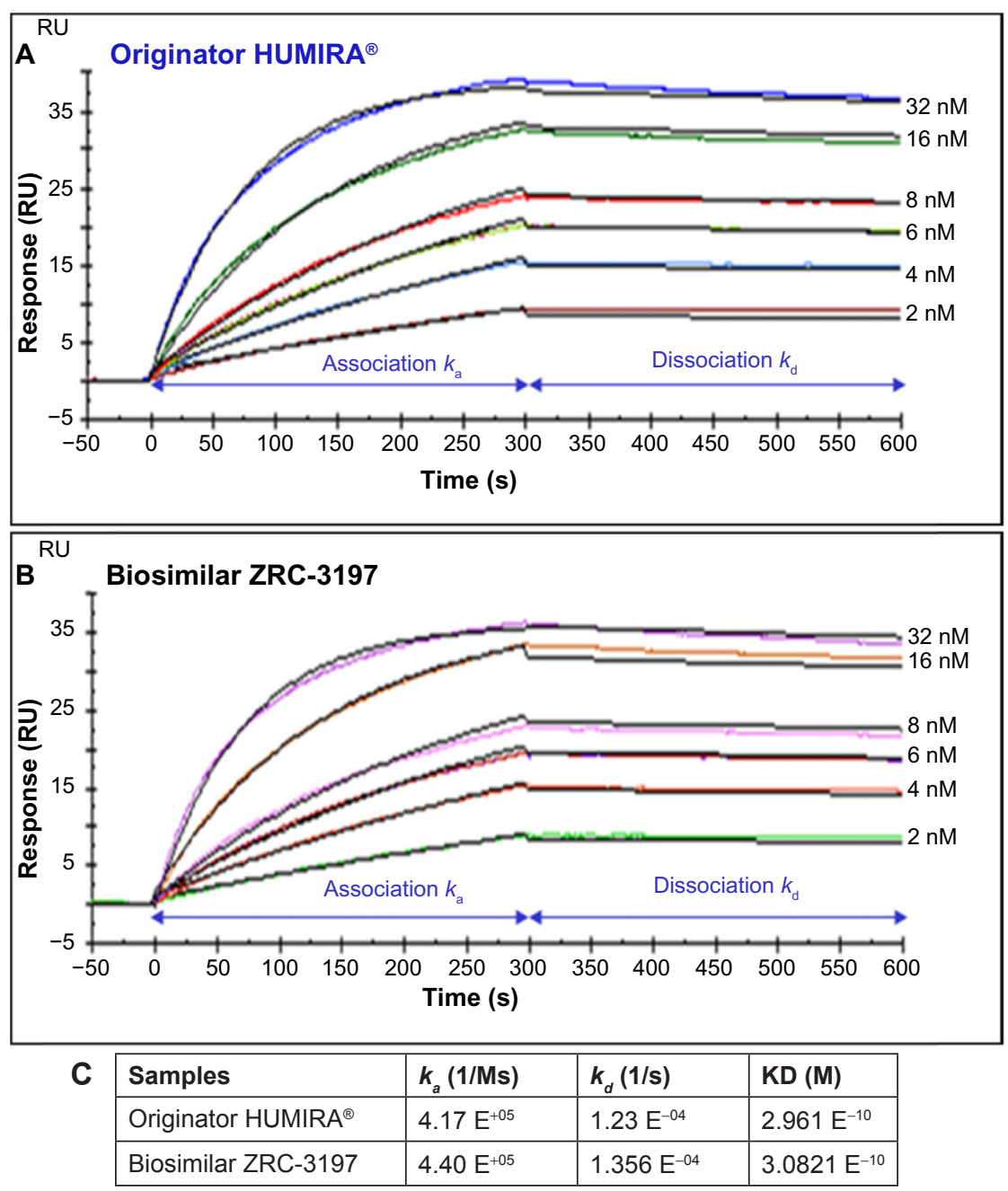

Figure 9 Comparative analysis of the biosimilar ZRC-3197 and originator HUMIRA ${ }^{\circledR}$ for affinity to recombinant human TNF- $\alpha$ by SPR. Kinetic analysis of TNF- $\alpha$ binding was performed by injecting different known concentrations of TNF solution (from $2 \mathrm{nM}$ to $32 \mathrm{nM}$ ) onto immobilized Protein A-bound adalimumab prepared from originator HUMIRA $^{\circledast}$ (A) and biosimilar ZRC-3197 (B), separately. For immobilization, carboxymethyl dextran-coated CM5 sensor chips were used with amine coupling chemistry. Different concentrations of R-HuTNF- $\alpha$ were injected onto the bound adalimumab at a flow rate of $25 \mu \mathrm{L} / \mathrm{min}$ for 300 seconds to check the kinetics of association. For dissociation of TNF, HBS-EP+ buffer was injected at a flow rate of $25 \mu \mathrm{L} / \mathrm{min}$ for 300 seconds. Biosensor matrices were regenerated after each run using glycine-HCl buffer at $\mathrm{pH}$ 2.0. Biacore T200 evaluation software (version 1.0) was used to determine $k_{d}$ (dissociation constant) and $k_{a}$ (association constant) values. KD (equilibrium constant) values were calculated from the obtained $k_{d}$ and $k_{a}$ values shown in the accompanying table (C).

Abbreviations: SPR, surface plasmon resonance; TNF- $\alpha$, tumor necrosis factor-alpha; HBS-EP+ buffer, HEPES [4-\{2-hydroxyethyl\}-I-piperazineethanesulfonic acid], NaCl, EDTA [ethylenediaminetetraacetic acid], and Surfactant P20; min, minutes; s, seconds; R-Hu-TNF- $\alpha$, recombinant human TNF- $\alpha$.

\section{Conclusion}

The indigenously developed biosimilar adalimumab, ZRC-3197, has been extensively characterized for physicochemical and functional properties of the monoclonal antibody by using a set of orthogonal analytical techniques in comparison with the originator HUMIRA ${ }^{\circledR}$. Physicochemical characterization of the biosimilar ZRC-3197 revealed a high level of sameness as that of the originator HUMIRA ${ }^{\circledR}$. Primary structure and molecular identity of the biosimilar ZRC-3197 were observed to be identical to the originator HUMIRA $^{\circledR}$, as confirmed by peptide mapping, amino acid sequencing, $\mathrm{N}$ - and $\mathrm{C}$-terminal sequencing, and molecular mass determination using a wide range of MS techniques.
The biosimilar ZRC-3197 was observed to show indistinguishable protein secondary structure and $\mathrm{S}-\mathrm{S}$ cross-links from the originator HUMIRA ${ }^{\circledR}$, as assessed by CD spectroscopy and MS, respectively. Both products appeared to show predominantly $\beta$ structure of protein and correct formation of S-S cross-links. These results confirmed the identical structural conformity of the two products. Given that different molecular weight species variants, mainly the aggregates of monoclonal antibodies, can enhance immunogenicity while affecting the in vivo safety and efficacy of the medicinal products, purity of the biosimilar ZRC-3197 was assessed by a set of orthogonal analytical methods in comparison with originator HUMIRA ${ }^{\circledR} .{ }^{19-21}$ HP-SEC, 


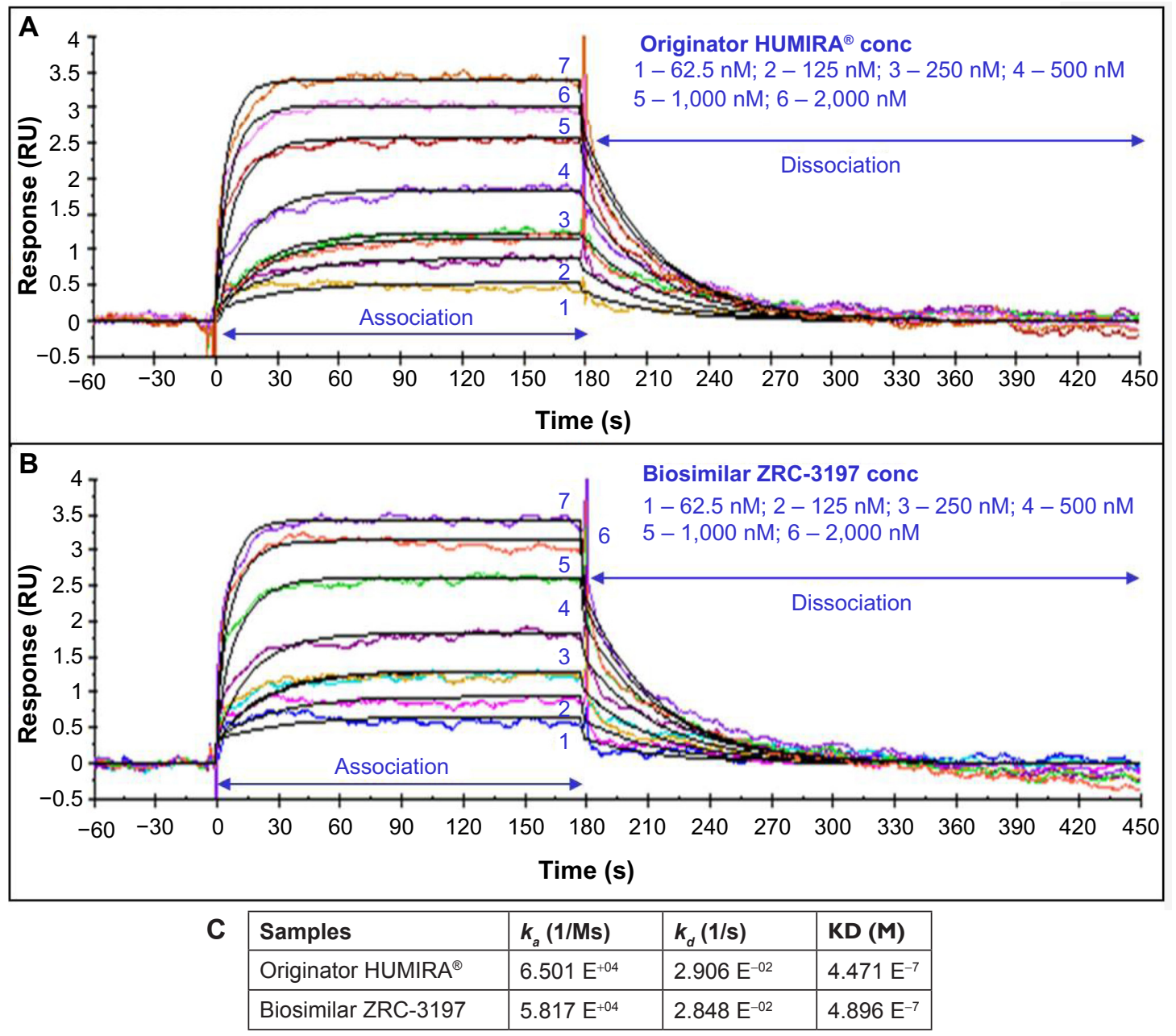

Figure 10 Comparative analysis of originator HUMIRA ${ }^{\circledR}(\mathbf{A})$ and biosimilar ZRC-3197 (B) for affinity to recombinant human Fc $\gamma R$ Illa (CDI6) receptor by SPR. Kinetics of affinity of ZRC-3197 and originator HUMIRA ${ }^{\circledR}$ for recombinant human FcyRIlla receptor immobilized on CM5 sensor chip was assessed by SPR. Different concentrations of the biosimilar ZRC-3197 or originator product solution were injected on the immobilized receptor at a flow rate of $30 \mu \mathrm{L} / \mathrm{min}$ for 180 seconds to check the kinetics of association. For dissociation of adalimumab from the receptor site, PBS-P+ buffer was injected at $30 \mu \mathrm{L} / \mathrm{min}$ for 300 seconds. Biacore T200 evaluation software (version I.0) was used to determine $k_{d}$ (dissociation constant) and $k_{a}$ (association constant) values. KD (equilibrium constant) values for Fc $\gamma$ RIIla receptor were calculated from the obtained $k_{d}$ and $k_{a}$ values shown in the accompanying table $(\mathbf{C})$.

Abbreviations: PBS-P+ buffer, phosphate buffer, $\mathrm{NaCl}, \mathrm{KCl}$, and Surfactant P20; SPR, surface plasmon resonance; s, seconds; conc, concentration.

being one of the major methods to characterize the protein aggregates, was applied to assess the purity of the samples. In HP-SEC analysis, the biosimilar ZRC-3197 was observed to show a highly similar level of purity with a very low level of aggregates $(<0.5 \%)$, as observed compared with that of the originator product. In SDS-PAGE and CE-SDS analysis, the biosimilar ZRC-3197 was observed to show indistinguishable pattern of size heterogeneity and level of purity from the originator HUMIRA ${ }^{\circledR}$. These results demonstrated a high level of biosimilarity of the ZRC-3197 product with respect to the originator HUMIRA ${ }^{\circledR}$ in terms of purity and overall molecular integrity.

Given that different type and level-of-charge heterogeneity and post-translation modifications can substantially affect the in vitro and in vivo properties of monoclonal antibodies, the biosimilar ZRC-3197 was analyzed by HP-IEC, cIEF, and MS, and compared with the originator HUMIRA ${ }^{\circledR}$ to assess the charge heterogeneity profile. ${ }^{22-27}$ The biosimilar ZRC-3197 was observed to show highly comparable charge variants (Lys-variants) and nearly identical $\mathrm{pI}$ value(s) for the major and minor charged species variants with respect to the originator HUMIRA ${ }^{\circledR}$, as illustrated by HP-IEC and cIEF, respectively. MS analysis of the peptide fragments derived from various proteolytic enzyme digestions of the biosimilar ZRC-3197 and originator HUMIRA ${ }^{\circledR}$ exhibited highly similar level of Met-oxidation and deamidation of certain Gln/Asn amino acids, which were common for both products. Very low levels of oxidation and deamidation were characteristically observed with the two products. However, no such modifications were observed to take 


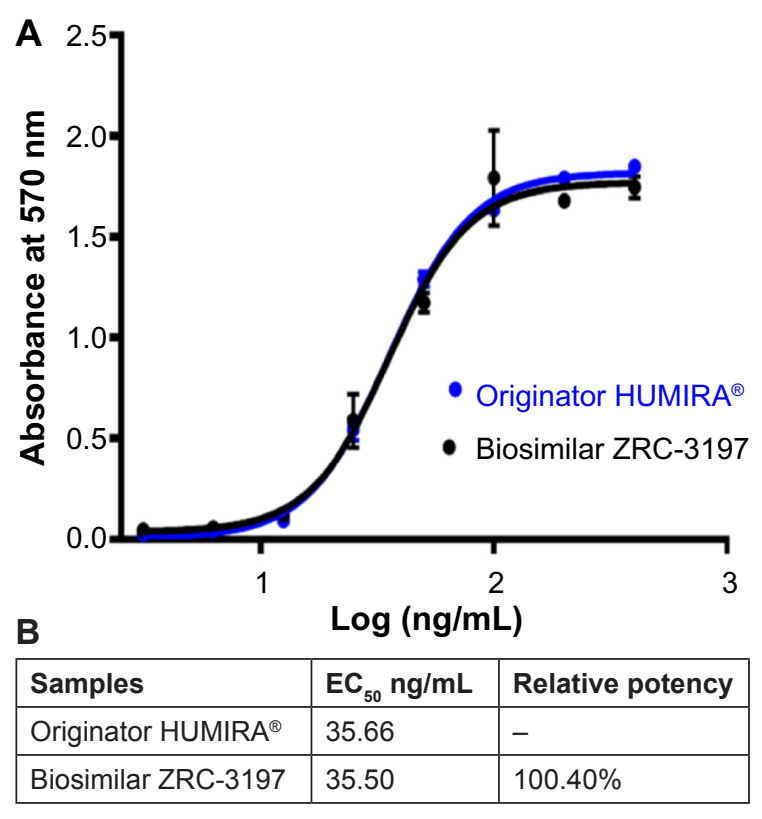

Figure II $r$-HuTNF- $\alpha$ neutralizing activity by cell-based L929 assay: comparison between the biosimilar ZRC-3197 and originator HUMIRA ${ }^{\circledR}$. TNF-neutralizing activity was estimated by a MTT reduction assay on $L 929$ cells. Assays were conducted, in parallel, with the biosimilar ZRC-3197 and originator HUMIRA ${ }^{\circledR}$ (A). Solutions of TNF- $\alpha$ were mixed with different concentrations of adalimumab samples, for neutralization. Aliquots $(100 \mathrm{~mL})$ of sample mixture were applied on to 96 -well plates containing the L929 cell culture and incubated for 24 hours at $37^{\circ} \mathrm{C}$. MTT assay was performed to check the proliferation of cells at $570 \mathrm{nM}$. EC 50 values $(\mathrm{ng} / \mathrm{mL})$ were determined from the dose-response curve generated with the biosimilar ZRC-3197 and originator product, separately. TNF- $\alpha$ neutralizing activity of ZRC-3197 was expressed as a relative potency with respect to the originator HUMIRA $^{\circledR}$, as shown in the accompanying table (B).

Abbreviations: MTT, 3-(4,5-dimethylthiazol-2-yl)-2,5-diphenyltetrazoliumbromide; $\mathrm{EC}_{50}$, half maximal effective concentration; TNF- $\alpha$, tumor necrosis factor alpha; $r-H u T N F-\alpha$, recombinant human TNF- $\alpha$.

place in the CDR regions (CDR L1, RASQGIRNYLA; CDR L2, AASTLQS; CDR L3, QRYNRAPYT; CDR H1, DYAMH; CDR H2, AITWNSGHIDYADSVEG; and CDR H3, VSYLSTASSLDY) of adalimumab present either in ZRC-3197 or originator HUMIRA ${ }^{\circledR}$. It is evident from the crystal structure of TNF- $\alpha$ in complex with the adalimumab Fab reported at $3.1 \AA$ resolution that the CDR loops L1, L2, L3, H1, H2, and H3 of adalimumab form a large deep pocket to accommodate the TNF binding epitopes. ${ }^{16}$ The crystal structure has also revealed that adalimumab binds to TNF- $\alpha$ at the receptor binding sites, covering a larger surface area of the antigen (TNF- $\alpha$ )-antibody (adalimumab) interface. Therefore, it is reasonable to predict that in the absence of any detectable modifications in the CDR regions, the two products are not expected to show any difference in binding affinity to TNF- $\alpha$. These results together demonstrated a high level of sameness of the charge heterogeneity pattern, in general, and amino acid modifications, in particular, between the biosimilar ZRC-3197 and originator HUMIRA ${ }^{\circledR}$.
Since the type and degree of glycosylation is known to play a very important role in demonstrating the in vivo efficacy and half-life of monoclonal antibody products, it was important to analyze the carbohydrate structure of the biosimilar ZRC-3197 and originator HUMIRA ${ }^{\circledR}$ on a comparative basis. ${ }^{28}$ In glycan analysis, the biosimilar ZRC-3197 and originator HUMIRA ${ }^{\circledR}$ were observed to show the presence of G0F carbohydrate moiety, as the predominant variant (approximately $70 \%-75 \%$ ) among the other glycan variants, as shown in Table 2. No significant differences in other minor glycan variants were observed between the two products. Glycan analysis by UHPLC also indicated that the biosimilar ZRC-3197 contained a very low level of sialylated (A1F) variant like that of the originator HUMIRA $^{\circledR}$. Results obtained from HPAEC-PAD analysis for monosaccharides (Table 3) revealed that the glycan moieties present in the two products were mainly composed of similar levels of fucose, glucosamine, mannose, and galactose. Through peptide mapping by MS, a common glycosylation site at the position $\mathrm{Asn}^{301}$ on the heavy chain of biosimilar ZRC-3197 and originator HUMIRA ${ }^{\circledR}$ was confirmed. CE-SDS analysis, under reduced conditions, revealed more than $98 \%$ glycosylation occupancy of the heavy-chain components of the two products. These results together clearly demonstrated the sameness of carbohydrate structures of the biosimilar ZRC-3197 as compared to that of the originator HUMIRA ${ }^{\circledR}$.

Since the primary mechanism of action of adalimumab involves the binding of TNF- $\alpha$, the ability of the biosimilar ZRC-3197 to bind (neutralizing activity) to TNF with respect to the originator HUMIRA ${ }^{\circledR}$ was assessed by an in vitro cell-based assay using the L929 cell line. In the L929 cell-based assay, the biosimilar ZRC-3197 was observed to show nearly identical $\mathrm{EC}_{50}$ value with a potency ratio of approximately $100 \%$, as compared to that of the originator HUMIRA ${ }^{\circledR}$. Furthermore, when analyzed by SPR, the biosimilar ZRC-3197 showed highly comparable affinity (KD value) to TNF- $\alpha$ with respect to that of the originator product. The rate and extent of association $\left(k_{a}\right)$ and dissociation $\left(k_{d}\right)$ between TNF- $\alpha$ and adalimumab were observed to be highly comparable between the two products. Given that adalimumab also functions through Fc $\gamma$ receptors, the affinity of ZRC-3197 for one of the relevant receptors, Fc $\gamma$ RIIIa (or CD16), was determined by SPR and compared with the originator HUMIRA ${ }^{\circledR}$. ZRC-3197 was observed to show highly comparable KD values $\left(k_{a}\right.$ and $\left.k_{d}\right)$ for Fc $\gamma R$ III a receptor in comparison with the originator HUMIRA ${ }^{\circledR}$. From a separate SPR-based experiment, ZRC-3197 was also observed 
to exhibit a highly comparable affinity constant for FcRn receptor as compared to that of the originator HUMIRA ${ }^{\circledR}$ (data not shown). These results together confirm the sameness of the main functional properties of the biosimilar ZRC-3197 and originator HUMIRA ${ }^{\circledR}$.

Subsequent to the thorough characterization of physicochemical and functional properties of the biosimilar ZRC3197 , a comparative animal toxicity study was conducted to evaluate safety of the product in accordance with the national regulatory guidelines following Good Laboratory Practices.$^{29}$ No significant differences between the biosimilar ZRC-3197 and originator HUMIRA ${ }^{\circledR}$ were observed through the comparative toxicological studies in animals. The biosimilar ZRC-3197 was observed to exhibit an overlapping pharmacokinetics profile compared to that of the originator HUMIRA ${ }^{\circledR}$ following a single-dose injection in rats. Clinical safety and efficacy of the biosimilar ZRC-3197 has also been established through a multi-centric, prospective, randomized, double-blind, active controlled parallel study arm in patients with rheumatoid arthritis between the ages of $\geq 18$ and $\leq 65$ years (trial no CTRI/2013/10/004040). The study was conducted in India as per the guidance of CDSCO (Ministry of Health and Family Welfare, Government of India) and by following the guidelines of International Conference on Harmonization - Good Clinical Practice (ICH-GCP). ${ }^{30}$ Overall, in the head-to-head trial, the biosimilar ZRC-3197 was observed to exhibit highly similar level of efficacy, safety, and tolerability of the drug in rheumatoid arthritis patients, as compared to that of the originator HUMIRA ${ }^{\circledR}$.

Based on the demonstrated biosimilarity of ZRC-3197, Cadila Healthcare, Ahmedabad, Gujarat, India, has received the marketing authorization for ZRC-3197 from Directorate General of Health Services, CDSCO, in India.

\section{Acknowledgments}

Cadila Healthcare Ltd, the Zydus group, Ahmedabad, Gujarat, India, funded the whole development program of the ZRC-3197 project. The experimental activity, data analysis, and interpretation of data were performed by the authors and the ZRC-3197 project team members. All the project team members are acknowledged for their contribution to the development of the biosimilar ZRC-3197. The authors would also like to acknowledge Ms Anita Nair for her help in the literature search.

\section{Disclosure}

The authors report no conflicts of interest in this work.

\section{References}

1. European Medicines Agency. Guideline on Similar Biological Medicinal Products Containing Biotechnology-derived Proteins as Active Substance: Quality Issues (Revision 1). London: European Medicines Agency; Available from: http://www.ema.europa.eu/docs/en_GB/ document_library/Scientific_guideline/2014/06/WC500167838.pdf.

2. US Department of Health and Human Services Food and Drug Administration. Biological Medicinal Products Containing Biotechnology-derived Proteins as Active Substance: Non-clinical and Clinical Issues (Draft). London: European Medicines Agency; 2013. Available from: http://www.ema.europa.eu/docs/en_GB/ document_library/Scientific_guideline/2013/06/WC500144124.pdf.

3. US Food and Drug Administration. Scientific Considerations in Demonstrating Biosimilarity to a Reference Product (Draft Guidance). Rockville, MD: US Food and Drug Administration; 2012. Available from: http://www.fda.gov/downloads/drugs/guidancecomp lianceregulatoryinformation/guidances/ucm291128.pdf.

4. European Medicines Agency. Guideline on Similar Biological Medicinal Products Containing Monoclonal Antibodies - Non-clinical and Clinical Issues. European Medicines Agency; 2012. Available from: http://www.ema.europa.eu/docs/en_GB/document_library/ Scientific_guideline/2012/06/WC500128686.pdf.

5. Central Drugs Standard Control Organization (CDSCO). Guidelines on Similar Biologics: Regulatory Requirements for Marketing Authorization in India. Central Drugs Standard Control Organization; 2012. Available from: http://www.cdsco.nic.in/writereaddata/Bio\%20 Similar\%20Guideline.pdf.

6. Brekke OH, Sandlie I. Therapeutic antibodies for human diseases at the dawn of the twenty-first century. Nat Rev Drug Discov. 2003;2(1): $52-62$.

7. Reichert JM. Trends in US approvals: new biopharmaceuticals and vaccines. Trends Biotechnol. 2006;24(7):293-298.

8. Visser J, Feuerstein I, Stangler T, Schmiederer T, Fritsch C, Schiestl M. Physicochemical and functional comparability between the proposed biosimilar rituximab GP2013 and originator rituximab. BioDrugs. 2013,2(5)7:495-507.

9. da Silva A, Kronthaler U, Koppenburg V, et al. Target-directed development and preclinical characterization of the proposed biosimilar rituximab GP2013. Leuk Lymphoma. 2014;55(7):1609-1617.

10. Salfeld GJ, Allen DJ, Hendricus RJM, et al, inventors; BASF Aktiengesellschaft, assignee. Human antibodies that bind human TNF $\alpha$. United States patent US 6258562 B1. July 10, 2001.

11. Carson GR, Gion W, Salfeld GJ et al, inventors; Abbott Laboratories, applicant. Multiple gene expression including sORF constructs and methods with polyproteins, pro-proteins and proteolysis. WO/2007/014162 A2. February 1, 2007.

12. Wan M, Avgerinos G, Zarbis-Papastoitsis G, inventors; Lahive and Cockfield, LLP/Abbott, assignee. Antibody purification. United States patent US 20070292442A1. December 20, 2007.

13. European Pharmacopoeia 8.2. Electrophoresis. Numerics. 2.2.31: $47-51$.

14. Trost LC, Lemasters JJ. A cytotoxicity assay for tumor necrosis factor employing a multiwell fluorescence scanner. Anal Biochem. 1994;220(1):149-153.

15. Tracey D, Klareskog L, Sasso EH, Salfeld JG, Tak PP. Tumor necrosis factor antagonist mechanisms of action: a comprehensive review. Pharmacol Ther. 2008;117(2):244-279.

16. Hu S, Liang S, Guo H, et al. Comparison of the inhibition mechanisms of adalimumab and infliximab in treating tumor necrosis factor $\alpha$-associated diseases from a molecular view. $J$ Biol Chem. 2013; 288(38):27059-27067.

17. Radaev S, Sun P. Recognition of immunoglobulins by Fc $\gamma$ receptors. Mol Immunol. 2002;38(14):1073-1083.

18. Tutuncu Z, Kavanaugh A, Zvaifler N, Corr M, Deutsch R, Boyle D. Fc-gamma receptor type IIIA polymorphisms influence treatment outcomes in patients with inflammatory arthritis treated with tumor necrosis factor alpha-blocking agents. Arthritis Rheum. 2005;52(9):2693-2696. 
19. Rosenberg AS. Effects of protein aggregates: an immunologic perspective. AAAPS J. 2006;8(3):E501-E507.

20. den Engelsman J, Garidel P, Smulders R, et al. Strategies for the assessment of protein aggregates in pharmaceutical biotech product development. Pharm Res. 2011;28(4):920-933.

21. Berkowitz SA, Engen JR, Mazzeo JR, Jones GB. Analytical tools for characterizing biopharmaceuticals and the implications for biosimilars. Nat Rev Drug Discov. 2012;11(7):527-540.

22. Du Y, Walsh A, Ehrick R, Xu W, May K, Liu H. Chromatographic analysis of the acidic and basic species of recombinant monoclonal antibodies. MAbs. 2012;4(5):578-585.

23. Khawli LA, Goswami S, Hutchinson R, et al. Charge variants in IgG1: isolation, characterization, in vitro binding properties and pharmacokinetics in rats. MAbs. 2010;2(6):613-624.

24. Chelius D, Rehder DS, Bondarenko PV. Identification and characterization of deamidation sites in the conserved regions of human immunoglobulin gamma antibodies. Anal Chem. 2005;77(18):6004-6011.

25. Chumsae C, Gaza-Bulseco G, Sun J, Liu H. Comparison of methionine oxidation in thermal stability and chemically stressed samples of a fully human monoclonal antibody. J Chromatogr B Analyt Technol Biomed Life Sci. 2007;850(1-2):285-294.
26. Johnson KA, Paisley-Flango K, Tangarone BS, Porter TJ, Rouse JC. Cation exchange-HPLC and mass spectrometry reveal C-terminal amidation of an IgG1 heavy chain. Anal Biochem. 2007;360(1): $75-83$.

27. Beck A, Wagner-Rousset E, Ayoub D, Van Dorsselaer A, SanglierCianférani S. Characterization of therapeutic antibodies and related products. Anal Chem. 2013;85(2):715-736.

28. Hossler P, Khattak SF, Li ZJ. Optimal and consistent protein glycosylation in mammalian cell culture. Glycobiology. 2009;19(9):936-949.

29. Ministry of Health and Family Welfare. Drugs and Cosmetics (IInd Amendment) Rules, 2005. New Delhi: Ministry of Health and Family Welfare; 2005. Available from: http://dbtbiosafety.nic.in/act/schedule_y. pdf.

30. Cadila Healthcare Limited. A study to evaluate efficacy, tolerability and safety of adalimumab (Zydus) and adalimumab (reference) in patients with rheumatoid arthritis (REF/2013/09/005755). Available from: http://ctri.nic.in. CTRI identifier: CTRI/2013/10/004040. Accessed November 7, 2014.
Biosimilars

\section{Publish your work in this journal}

Biosimilars is an international, peer-reviewed, open access journal focusing on the manufacture, development and medicinal use of biopharmaceutical compounds considered similar to an innovator agent. Specific topics covered in the journal include: Regulatory issues and pathways; manufacturing processes; chemical composition and

\section{Dovepress}

structure; quality and purity; patent issues; bioequivalence and interchangeability; clinical efficacy data; patient perspectives. The manuscript management system is completely online and includes a very quick and fair peer-review system. Visit http://www.dovepress.com/ testimonials.php to read real quotes from published authors. 